San Jose State University

SJSU ScholarWorks

Master's Theses

Master's Theses and Graduate Research

1992

\title{
Habitat use, diet, and parasitism of the seastar Rathbunaster californicus fisher from the Monterey Submarine Canyon, California
}

Lynn Morgan Lewis

San Jose State University

Follow this and additional works at: https://scholarworks.sjsu.edu/etd_theses

\section{Recommended Citation}

Lewis, Lynn Morgan, "Habitat use, diet, and parasitism of the seastar Rathbunaster californicus fisher from the Monterey Submarine Canyon, California" (1992). Master's Theses. 336.

DOI: https://doi.org/10.31979/etd.4qnh-d598

https://scholarworks.sjsu.edu/etd_theses/336

This Thesis is brought to you for free and open access by the Master's Theses and Graduate Research at SJSU ScholarWorks. It has been accepted for inclusion in Master's Theses by an authorized administrator of SJSU ScholarWorks. For more information, please contact scholarworks@sjsu.edu. 


\section{INFORMATION TO USERS}

This manuscript has been reproduced from the microfilm master. UMI films the text directly from the original or copy submitted. Thus, some thesis and dissertation copies are in typewriter face, while others may be from any type of computer printer.

The quality of this reproduction is dependent upon the quality of the copy submitted. Broken or indistinct print, colored or poor quality illustrations and photographs, print bleedthrough, substandard margins, and improper alignment can adversely affect reproduction.

In the unlikely event that the author did not send UMI a complete manuscript and there are missing pages, these will be noted. Also, if unauthorized copyright material had to be removed, a note will indicate the deletion.

Oversize materials (e.g., maps, drawings, charts) are reproduced by sectioning the original, beginning at the upper left-hand corner and continuing from left to right in equal sections with small overlaps. Each original is also photographed in one exposure and is included in reduced form at the back of the book.

Photographs included in the original manuscript have been reproduced xerographically in this copy. Higher quality $6^{\prime \prime} \times 9^{\prime \prime}$ black and white photographic prints are available for any photographs or illustrations appearing in this copy for an additional charge. Contact UMI directly to order.

\section{$\mathrm{U} \cdot \mathrm{M} \cdot \mathrm{I}$}

University Microfilms International

A Bell \& Howell Information Company

300 North Zeeb Road. Ann Arbor. MI 48106-1346 USA

$313: 761.4700 \quad 800: 521-0600$ 
Habitat use, diet, and parasitism of the seastar Rathbunaster californicus Fisher from the Monterey Submarine Canyon, California

Lewis, Lynn Morgan, M.S.

San Jose State University, 1992 


\title{
HABITAT USE, DIET, AND PARASITISM OF THE SEASTAR RATHBUNASTER CALIFORNICUS FISHER FROM THE MONTEREY SUBMARINE CANYON, CALIFORNIA.
}

\author{
A Thesis \\ Presented to \\ The Faculty of Moss Landing Marine Laboratories \\ San Jose State University \\ In Partial Fulfillment \\ of the Requirements for the Degree \\ Master of Science
}

by

Lynn Morgan Lewis

May, 1992 
APPROVED FOR MOSS LANDING MARINE LABORATORIES

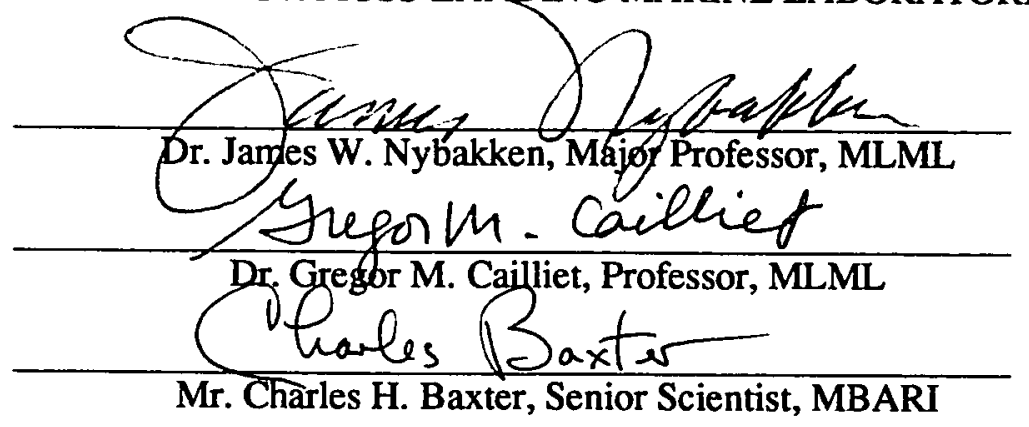

APPROVED FOR THE UNIVERSITY

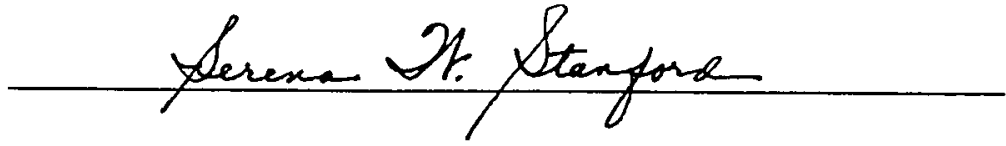




\section{ABSTRACT \\ HABITAT USE, DIET, AND PARASITISM OF THE SEASTAR RATHBUNASTER CALIFORNICUS FISHER FROM THE MONTEREY SUBMARINE CANYON, CALIFORNIA.}

by Lynn Morgan Lewis

Analysis of video data collected by a Remotely Operated Vehicle at four benthic sites in Monterey Submarine Canyon indicated that habitat use by the seastar Rathbunaster californicus varied from site to site, and in some cases, within depth intervals at the same site. Rathbunaster californicus was found to be a generalized benthic predator and scavenger, with a facultative ability to catch highly mobile benthopelagic prey. An endoparasitic eulimid gastropod was found inside the arms of $\underline{R}$. californicus from many sites in Monterey Bay, but infected seastars were more abundant at the Soquel site than at the C4-C5 site. The mean weight and mean gonad index of Soquel $\mathrm{R}$. californicus were lower than the means from C4-C5 specimens, but it is not known whether lower values were caused by presence of parasites. The parasite in $\underline{\mathbf{R}}$. californicus is probably a new species of Asterophila, and its presence in Monterey Bay extends the geographic range of this genus around the coastal North Pacific. 


\section{ACKNOWLEDGEMENTS}

First and foremost, I would like to thank Chuck Baxter. He has supported my educational and professional endeavors and has always been a source of inspiration, logic, and reason. This thesis never would have been started or finished without him. I would also like to thank Dr. James Nybakken, my major professor, and Dr. Gregor Cailliet, for their support and patience throughout the thesis process. I have enjoyed working with them immensely, and hope for continued interaction in the future. They, and many others, have made my experience at Moss Landing very rewarding.

My thesis topic originated through my work at the Monterey Bay Aquarium Research Institute (MBARI), and there are many people there who deserve recognition. George Matsumoto has been a great friend, reviewer, and editor, and he has helped me decrease my fear of public speaking...at least by a little bit. Bruce Robison supported me through the trials of being a student and full-time employee, and he arranged for me to have ROV dive time to complete my data collection. These data never would have been collected without the crew of the Pt. Lobos. Chris Grech, Craig Dawe, Steve Etchemendy, and Jim McFarlane deserve special thanks for their patience in flying the ROV on "Rathbunaster days," and for their ingenuity in collecting samples. Kurt Buck, Lisa Cooke, Annette Gough, Bruce Gritton, Steve Lowder, Andrea Sanico, Rich Schramm, and Marilyn Yuen all helped with data extraction, data presentation, and/or maintaining mental stability.

I also would like to thank Chuck Baxter, Gregor Cailliet, and Chris Harrold for helping define the habitat descriptors used in the habitat study, and Mike McNulty for helping me extract data from videos. Their ideas and intuition helped that study move forward smoothly.

Many thanks to Hilary and Mike McNulty and Mike Backstrom for being such supportive friends throughout this process, and for always knowing when enough was enough and it was time to take a break.

Last, but certainly not least, I'd like to thank my family--Mom, Dad, Ken, and Susan, for always being only a phone call away.

This research was supported by MBARI, Moss Landing Marine Laboratories, the Monterey Bay Aquarium, the Myers Trust, Hopkins Marine Station, California Fish and Game, Sea Grant, and the SEM facility at UCSC. 
TABLE OF CONTENTS

Page

Abstract

Acknowledgements

iii

List of Tables

List of Figures

iv

vi

vii

1. GENERAL INTRODUCTION 1

II. HABITAT UTILIZATION

Introduction

Materials and Methods

Results

7

Discussion

III. DIET

Introduction

Materials and Methods

36

Results

Discussion

IV. PARASITISM

Introduction

Materials and Methods

49

Results

53

Discussion

V. SUMMARY

LITERATURE CITED 


\section{LIST OF TABLES}

Page

Table 1. Habitat descriptions used to characterize habitat types in photo quadrats.

Table 2. Substrate descriptors used to characterize habitat types in photo quadrats.

Table 3. Preliminary results of habitat analysis.

Table 4. Percent Similarity Indices (PSI) of associated organisms and substrate types between the four sites sampled.

Table 5. Food of selected forcipulate asteroids.

Table 6. Prey items of Rathbunaster californicus. 


\section{LIST OF FIGURES}

Figure 1. In situ photograph of Rathbunaster californicus, with pedicellariae extended.

Figure 2. Map of Monterey Bay showing four benthic ROV dive sites.

Figure 3. Examples of the four most common substrate types found during video analysis.

Figure 4. Cumulative frequency curves of habitat types for each site.

Figure 5. Expected vs. observed number of frames containing Rathbunaster californicus for each substrate type at each site.

Figure 6. Percentage of frames and Rathbunaster californicus for each substrate type in $100 \mathrm{~m}$ intervals at Soquel.

Figure 7. Percentage of frames and Rathbunaster californicus for each substrate type in $100 \mathrm{~m}$ intervals at Carmel.

Figure 8. Percentage of frames and Rathbunaster californicus for each substrate type in $100 \mathrm{~m}$ intervals at C4-C5.

Figure 9. Percentage of frames and Rathbunaster californicus for each substrate type in $100 \mathrm{~m}$ intervals at Pt. Joe.

Figure 10. Megafaunal organisms associated with Rathbunaster californicus at each site.

Figure 11. Analysis of stomach contents of Rathbunaster californicus.

Figure 12. Photographs of parasitized Rathbunaster californicus, adult female Asterophila sp., and parasite veliger larvae.

Figure 13. Scanning Electron Micrographs of Asterophila sp. veliger larvae from Monterey Bay Rathbunaster californicus and Alaskan Leptasterias sp.

Figure 14. Maps of Monterey Bay showing location of parasitized Rathbunaster californicus.

Figure 15. Percent of parasitized Rathbunaster californicus during visual surveys at Soquel and C4-C5.

Figure 16. Percentage of Rathbunaster californicus infected by Asterophila sp. determined by visual methods vs. dissection. The comparison shows that visual methods alone can underestimate prevalence of the parasite. 
Figure 17. Arm Length (mm) vs. gonad weight (mg) for dissected Rathbunaster californicus from C4-C5.

page

Figure 18. Means and standard deviations of gonad index for dissected Rathbunaster californicus from C4-C5.

60

Figure 19. Arm Length (mm) vs. gonad weight (mg) for dissected Rathbunaster californicus from Soquel.

62

Figure 20. Means and standard deviations of gonad index for dissected Rathbunaster californicus from Soquel.

63 


\section{GENERAL INTRODUCTION}

Seastars are often conspicuous members of their communities, and since the mid-1960's, researchers have demonstrated the importance of asteroids in many shallow water and intertidal communities (Paine, 1966, 1969a, b; Dayton, 1971; Menge, 1972a; Rutherford, 1973; Birkeland, 1974; Dayton et al., 1974; Paine, 1974; Dayton, 1975; Menge, 1982; Sloan and Robinson, 1983; Annett and Pierotti, 1984). Seastars are found in all oceans from intertidal to abyssal depths, and are especially abundant as species along the northwest coast of North America (Verriii, 1909; Feder and Christensen, 1966; Lambert, 1981; Menge, 1982). Most seastars are successful opportunistic predators (Sloan, 1980; Jangoux, 1982). The combination of indeterminate growth, generalized digestive systems, extra- and/or intraoral digestion, sensory ability to respond to prey, methods of locomotion and attachment, and multiplicity of arms makes seastars unique organisms (Menge, 1982).

It is difficult to generalize about the effects of seastars on subtidal or abyssal communities because most information comes only from temperate intertidal systems. Some studies have been conducted on temperate, tropical, and Antarctic subtidal communities, but virtually nothing is known from deep-water habitats. A recent review by Menge (1982) on the effects of asteroids on their communities indicates that asteroid predation has an important role in organizing some marine benthic communities and that asteroids seem to fill similar roles in asteroid-dominated communities despite different evolutionary lineages and different geographical areas. Based on these generalizations from shallow-water communities, it is possible that seastars could be important members of deep-water communities where they are also abundant.

Because it is difficult to directly assess biotic interactions in the deep-sea environment, patterns of spatial dispersion of deep-living species have been used to generate hypotheses about deep-sea community structure (Bernstein and Meador, 
1979). Recent advances in deep-sea technology such as towed camera sleds, remotely operated vehicles (ROVs), and manned submersibles have been used to study dispersal patterns and generate such hypotheses.

Qualitative visual surveys conducted by ROV indicated that the forcipulate seastar Rathbunaster californicus Fisher (Fig. 1) was one of the most conspicuous and abundant megafaunal organisms in some areas of the Monterey Submarine Canyon, California (Fig. 2). Rathbunaster californicus ranges from southern Alaska to southern California (Austin, 1985) and is found between 60 and $1000 \mathrm{~m}$ in Monterey Bay (pers. obs). Very little is known about its natural history, at least partly because the autotomous nature of its 8-22 long flexible arms causes trawled specimens to be retrieved as a mass of arms and discs unsuitable for quantitative or laboratory study.

Fisher $(1906,1923,1928)$ described in detail the morphology and taxonomy of

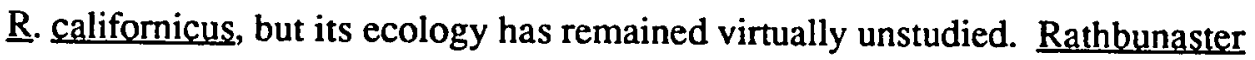
californicus is a member of the Asteriidae and is most closely related to species of Coronaster and Labidiaster. It also has been compared morphologically and ecologically to Pycnopodia helianthoides (Fisher, 1906, 1928). Rathbunaster califomicus exhibits the classic digestive system for asteroids: stomach and pyloric and rectal caeca (Jangoux, 1982). The arms bear long tube-feet with suction cups, straight pedicellariae, and spines surrounded by retractile wreaths of crossed pedicellariae. All of these are probably used for feeding (Verrill, 1909). The large eversible stomach almost completely occupies the coelom of the disc. Rathbunaster californicus is a mobile predator (Fisher, 1928; Carey, 1972), and it may have an important role in the energetics and ecology of the bathyal community of Monterey Bay.

Understanding the abundance, distribution, and natural history of $\underline{\mathrm{R}}$. californicus in Monterey Bay is a necessary precursor to testing hypotheses about this seastar's role in its community. The overall goal of this research was to examine the natural history 
of an abundant member of a deep-water habitat that has only recently become accessible to researchers. The specific objectives of this study were to assess patterns of habitat use, to determine the diet of $\underline{\mathrm{R}}$. californicus, and to characterize the relationship between an endoparasitic gastropod, Asterophila sp., and R. californicus in the Monterey Submarine Canyon. 


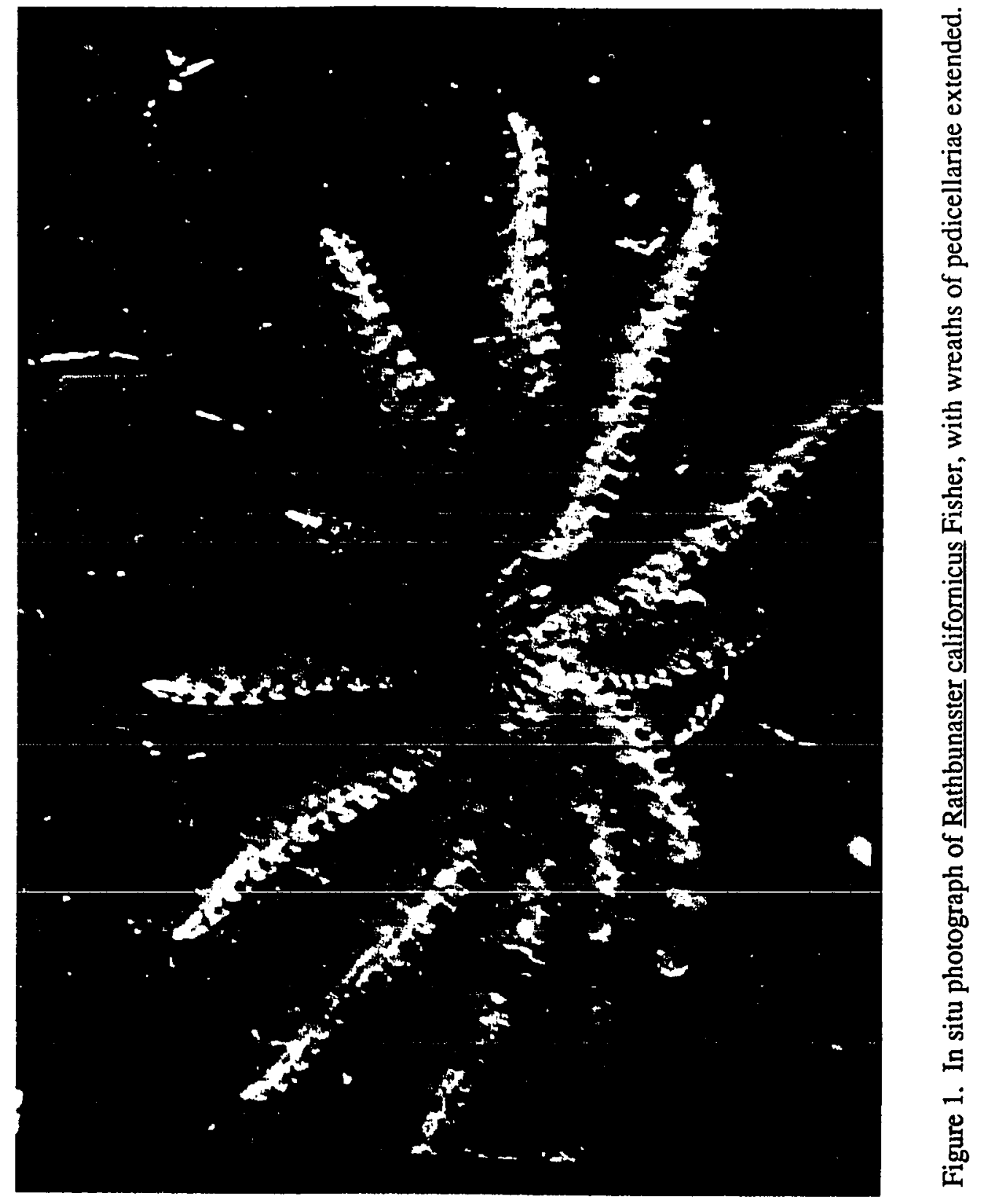




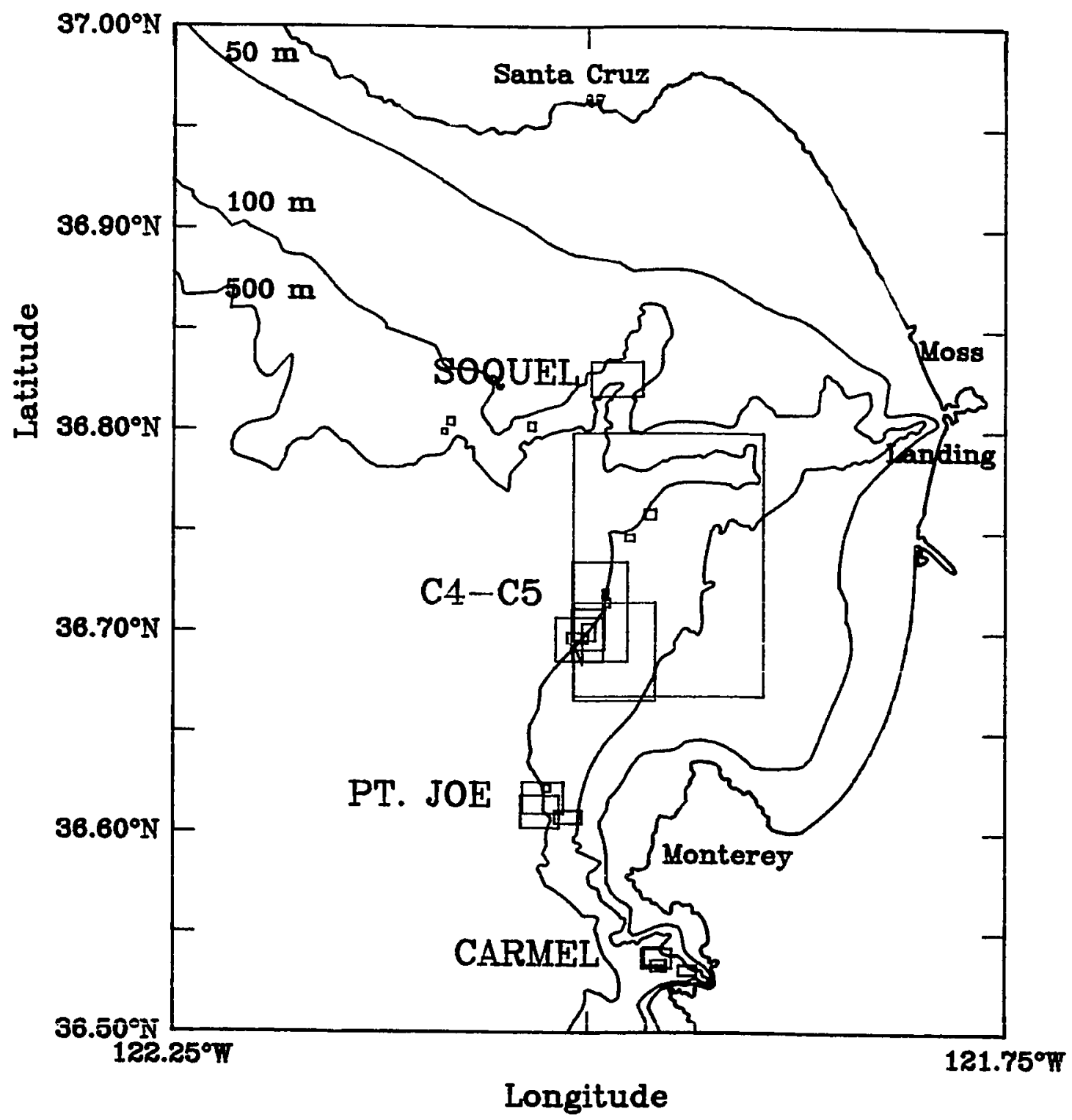

Figure 2. Map of Monterey Bay showing four benthic ROV dive sites. The north, east, south, and west extremes reached during a dive form the four corners of each box. 


\section{HABITAT USE BY RATHBUNASTER CALIFORNICUS: A ROV SURVEY IN THE MONTEREY SUBMARINE CANYON.}

\section{INTRODUCTION}

Analysis and interpretation of community dynamics depends in part on identifying and quantifying patterns of resource use (Krebs, 1989). For a benthic organism, food and space are essential resources for survival. A large database on feeding habits of shallow-living asteroids exists (Menge, 1982), but very little is known about habitat use by seastars. Aside from arbitrary division of seastars into assemblages based on bathymetry and geological formations (Alton, 1966), virtually nothing has been done to define resource use in deep-water habitats.

There are relatively few methods available to study deep-water habitats, and each has distinct advantages and disadvantages. Trawling is useful for making checklists of seastars present in some localities (Alton, 1966; Carey, 1972; McCauley, 1972; Austin, 1985), but is an ineffective method for studying the spatial distribution and abundance of organisms like Rathbunaster californicus. Rathbunaster californicus often inhabits rough terrain where trawling is not feasible, and the seastar is often fragmented when caught in nets, making it difficult to calculate abundance. Towed camera sleds, ROVs, and submersibles provide in situ mechanisms for studying abundance, distribution, and behavior of megafaunal organisms, and all have been used in Monterey Bay. In deep-sea habitats, estimates of abundance and distribution of benthic megafauna vary when using trawls, towed sleds, ROVs, and submersibles, and visual data collected by ROV or submersible are considered the most accurate for most megafaunal species (Uzmann et al., 1977; Butler et al., 1991). ROV and submersible observations permit estimation of intraspecific and interspecific spatial relationships, as well as substratum-related patterns of species distribution (Butler et al., 1991). 
Submersibles and ROVs are the most effective means of studying organisms inhabiting the rough terrain encountered in parts of Monterey Bay, and the close proximity of the Monterey Bay Aquarium Research Institute (MBARI) shore facility to the Monterey Submarine Canyon enables day trips with the ROV to visit deep-water study sites. Video data collected by ROV represent an ecological database useful for estimating the ablindance and distribution patterns of megafaunal organisms (e.g. Larson et al., in press).

Based on hours of qualitative review of video tapes prior to this study, it was hypothesized that $\underline{\mathrm{R}}$. californicus was most abundant on sediment slopes. The purpose of this part of the study was to quantitatively assess habitat use by $\underline{\mathrm{R}}$. californicus at four benthic sites in the Monterey Submarine Canyon by analysis of video data collected by ROV.

\section{MATERIALS AND METHODS}

To quantitatively assess the distribution of Rathbunaster californicus, with an emphasis on variation in abundance among habitat types, video data were collected with a ROV at four benthic sites in Monterey Submarine Canyon. The ROV was equipped with a conductivity, temperature, and depth sensor (CTD) and with several cameras (Etchemendy and Davis, 1991). Sensor data and the video signal from a 3-chip CCD Sony color camera were transmitted via fiber optic cable to the mother ship, the R/V PT. LOBOS, and video images recorded on BetaCam tape. The CTD, ship and ROV navigation, and video data were time stamped with Greenwich Mean Time (GMT) and could be correlated during post-processing. Maximum working depth of the vehicle for this study was $500 \mathrm{~m}$.

Video data were recorded during non-random surveys at several sites. All ROV dives between April 1989 and June 1990 were pooled for selection. Those without 
GMT, CTD, or navigation data were eliminated, leaving 24 dives from four general sites suitable for analysis. Four dives were from the Soquel site, four from Carmel, twelve from C4-C5, and four from Pt. Joe (Fig. 2). The Soquel and Carmel sites each represented a separate branch of the Monterey Submarine Canyon (i.e. Soquel Canyon and Carmel Canyon), and the dives occurred at or near a canyon axis. The C4-C5 and Pt. Joe sites were located along the steep canyon wall of the Monterey Canyon. Each site was different in its geology and availability of substrates.

For each dive, video and navigation data analyzed were restricted to periods when the vehicle was surveying the bottom. Navigation data from each dive were used to plot the north, east, south, and west boundaries of the area surveyed, and the position of the ROV at five minute intervals during a dive. The north, east, south, and west extremes reached on each ROV dive formed boxes representing the area of the canyon analyzed (Fig. 2). The dives at Carmel, C4-C5, and Pt. Joe were clustered, but the four dives at the Soquel site were spread out horizontally over several thousand meters.

Video tapes from the 24 dives were reviewed systematically to compile a collection of individual video frames for analysis. Each tape was stopped at 15 second intervals during the period the ROV remained near the bottom. Acceptance of a frame for analysis was based on several criteria. If the field of view appeared to be between one to ten meters wide at the base of the video screen, was in focus, well lit, on the bottom, not clouded by resuspended sediment or marine snow, and did not overlap with the previous frame, it was accepted and copied onto an optical disc. If doubt existed about quality or appropriate size of the frame, it was not analyzed. Tape identification, tape time-code, optical disc frame number, depth in meters, presence or absence of $\underline{R}$. californicus, number of $\underline{R}$. californicus, presence or absence of other megafauna, and habitat descriptions were recorded for each accepted frame. 
A committee of ROV users and other scientists familiar with the topography of the Monterey Submarine Canyon (see acknowledgements) met several times to create a list of habitat descriptors that would adequately characterize the habitats available to $\underline{R}$. californicus. The habitat in each video frame was described using all five categories of habitat descriptors (Table 1), but only data from the substrate category were used in subsequent analysis of habitat use by $\underline{\mathrm{R}}$. californicus (Table 2 ). The substrate descriptors (massive, boulders, cobble, gravel, mudstone, and sediment) were used in various combinations to produce the 17 substrate types used in video analysis (Table 2, Fig. 3). Video sequences preceding and following the extracted frame were used to clarify identification of $\underline{\mathrm{R}}$. californicus and categorization of habitat type. For example, if a frame contained a boulder in the middle of a sediment patch, but proceeding frames showed a $\underline{\mathrm{R}}$. californicus behind the boulder, the frame would be recorded as boulder/sediment with $\underline{\mathrm{R}}$. californicus present. Thus, substrate type, depth, presence/absence and numbers of $\underline{\mathrm{R}}$. californicus, and presence/absence of other megafauna were the data used in analysis.

To determine if the number of frames taken adequately represented the distribution of substrate types in each site, number of frames per substrate in ten-frame intervals were counted. Cumulative frequency curves were plotted for the five or six most abundant substrate types, and histograms of number of frames per substrate type were compared visually. The distribution of substrate types in the last two ten-frame intervals (e.g. 310 and 320 frames at Soquel) were compared by chi-square analysis $(\alpha=.05)$.

To determine habitat use by $\underline{\mathrm{R}}$. californicus within each site, data were first analyzed by substrate type only, discounting depth. Total number of frames, number of frames containing $\underline{\mathrm{R}}$. californicus, and total number of $\underline{\mathrm{R}}$. californicus per substrate type were tallied for each site. To test the null hypothesis that $\underline{\mathrm{R}}$. californicus was 

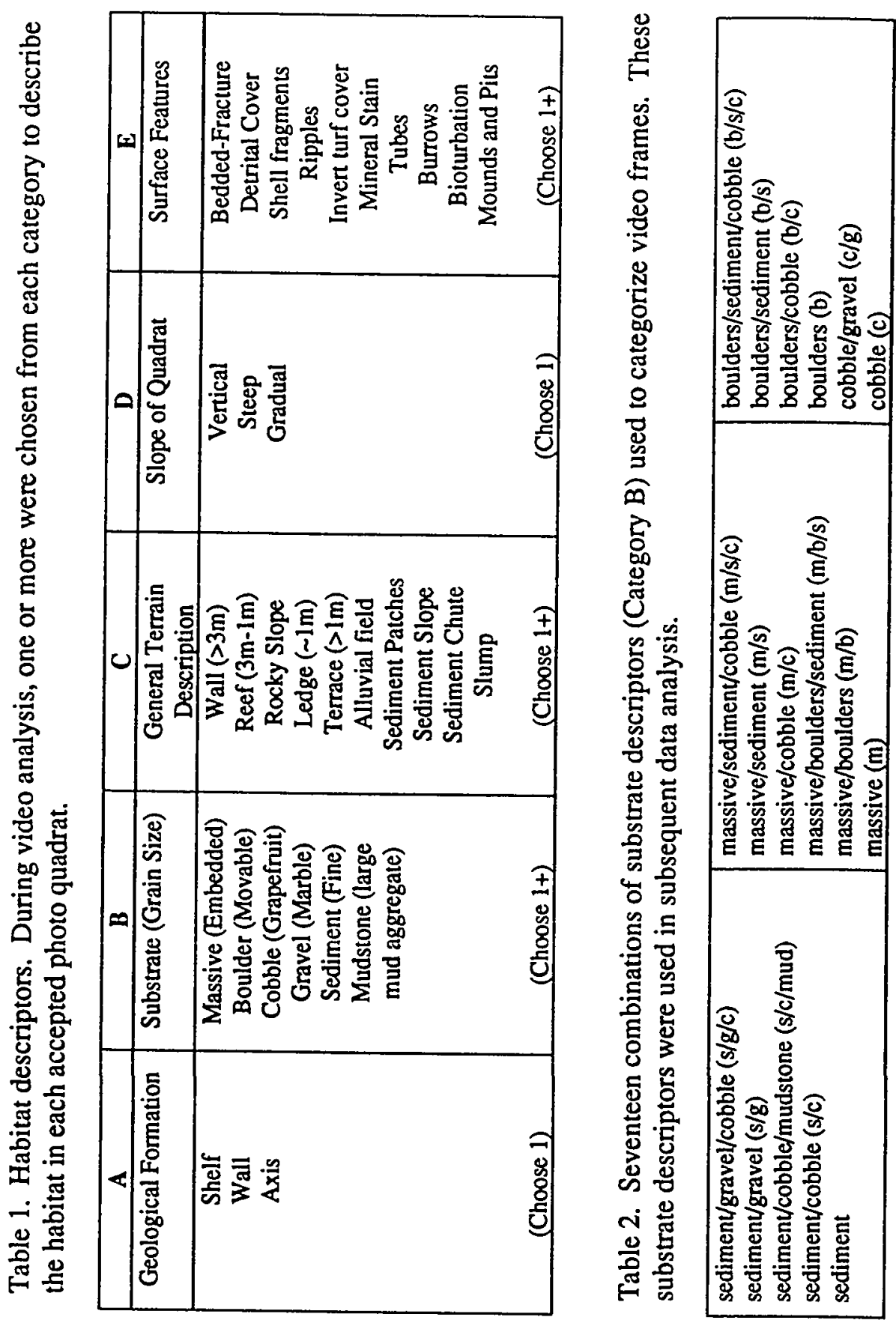

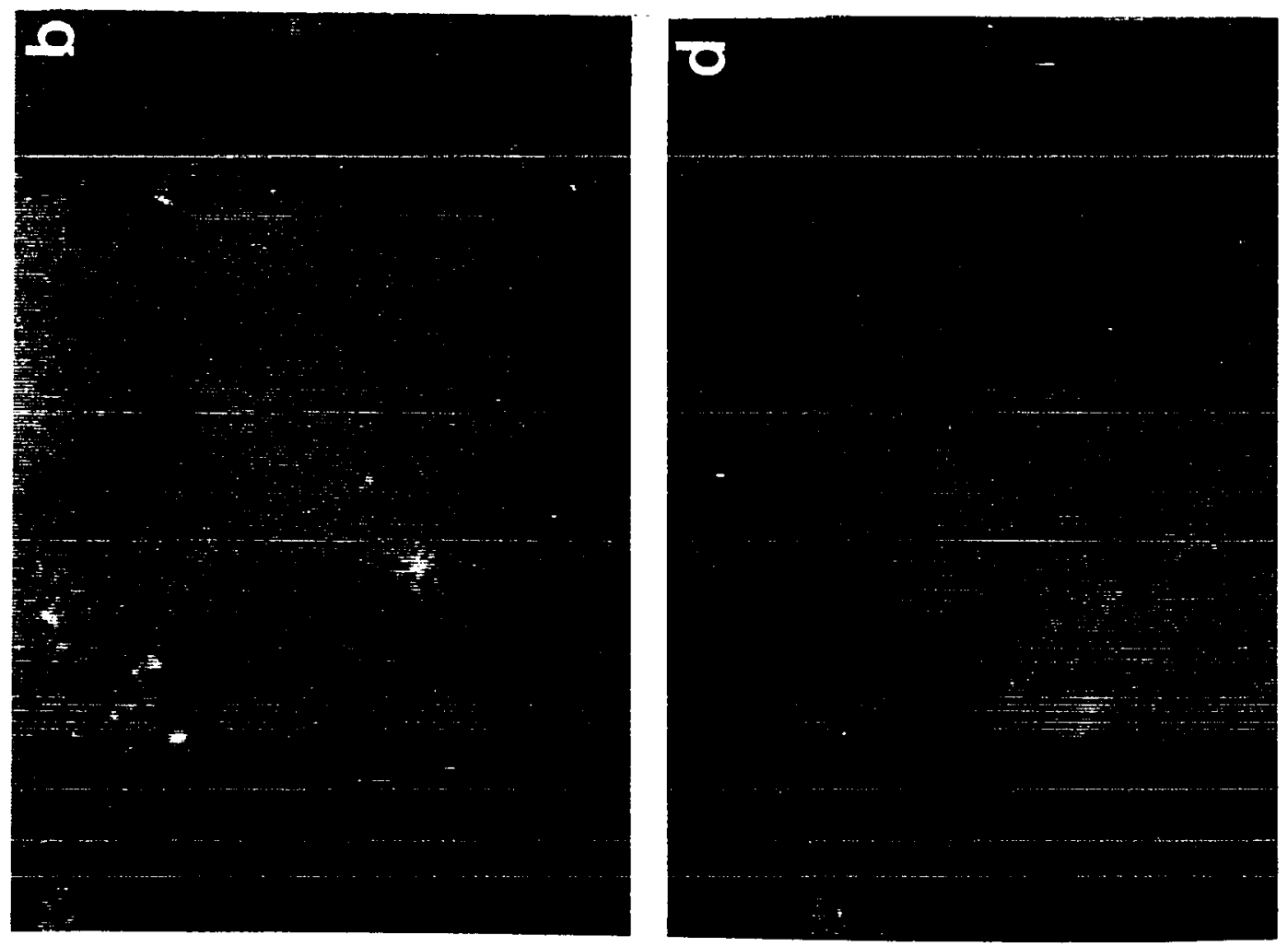

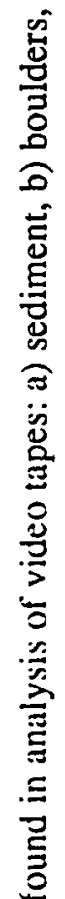
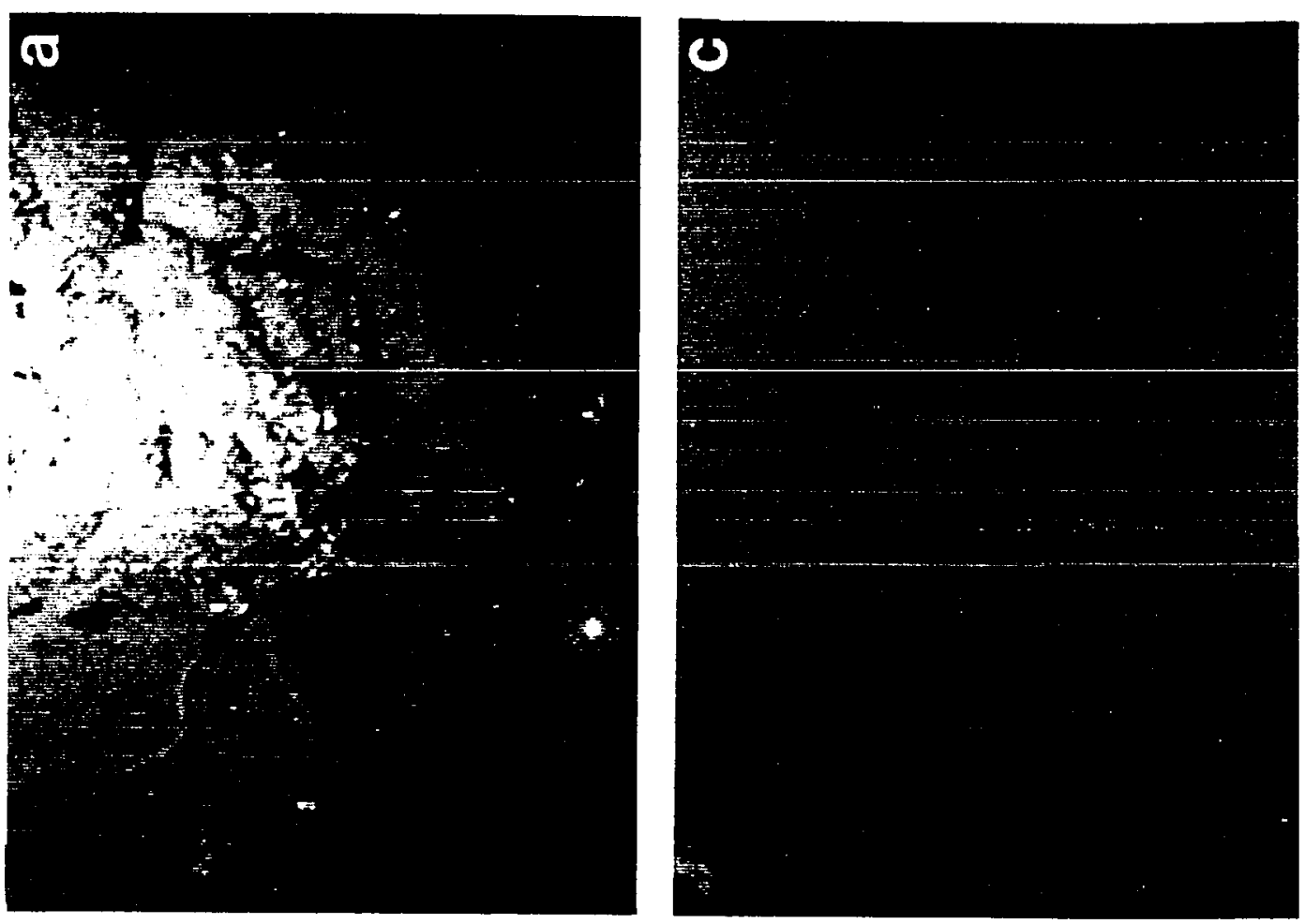

ئ.

5

ह ․ㅠㅇ

0

药

E

늘

옹

릉

पू

के

ह

E్్ㅀ

ศิ อ

$\dot{ }$

岁

学 
distributed in the same proportion that the substrates occurred, the observed proportion of frames from each substrate type that contained $\underline{R}$. californicus and the expected proportion ((number of frames per substrate type/total number of frames analyzed) $X$ total number of $\underline{\mathrm{R}}$. californicus) were plotted and compared using chi-square analysis $(\alpha=.05)$. Because there were small sample sizes in many substrate types, chi-square tests were repeated with data lumped into the broader categories of sediment, cobble, massive, or boulders. To determine if actual numbers of $\underline{\mathbf{R}}$. californicus per substrate type followed the patterns found for presence/absence data, the expected number of seastars in each substrate type also was calculated and compared to observed numbers of $\underline{R}$. californicus using chi-square analysis $(\alpha=.05)$.

Percentage of frames of each substrate type, frames containing $\underline{\mathbf{R}}$. californicus, and number of $\underline{R}$. californicus found in each substrate type were calculated. These data were then divided into $100 \mathrm{~m}$ depth intervals to investigate how depth contributed to habitat availability and habitat use by $\underline{R}$. californicus. Within each interval, number of frames and actual number of $\underline{\mathrm{R}}$. californicus per substrate type were compared by plotting substrate type against percent of total number of frames and seastars. Chisquare comparisons were not made because of small sample sizes in some of the depth intervals.

Presence or absence of megafaunal organisms in all frames containing $\mathbf{R}$. californicus were recorded to determine which associations were most common at each site, and these data were compared with histograms. At each site, proportion of frames containing each type of organism were standardized to $100 \%$, and percent similarity indices (PSI; Sanders, 1960) were calculated to compare arrays of organisms between sites. Percent similarity indices also were calculated (using number of frames per substrate type at each site) to compare the availability of substrate types between sites. 


\section{RESULTS}

Habitat utilization by Rathbunaster californicus was determined from 323 frames representing 11 substrate types from the Soquel site, 804 frames and 11 substrate types from Carmel, 810 frames and 8 substrate types from C4-C5, and 280 frames and 15 substrate types from Pt. Joe (Table 3). Seventeen substrate descriptions were used over all sites (Table 2).

The Soquel site was dominated by sediment, but boulders/sediment and massive each represented another $20 \%$ of the frames analyzed. A sufficient number of frames $(\mathrm{N}=323)$ was analyzed to characterize the substrate distribution at Soquel. Cumulative frequency curves stabilized for all substrate types by 90 frames, and no significant difference was found in substrate distribution between the last two ten-frame intervals (Fig. 4a, chi-square, p>.05).

Carmel was dominated by sediment and was almost monotypic (Fig. 4b). None of the other substrate types was found in more than $10 \%$ of the frames. An adequate number of frames was analyzed to characterize this site $(\mathrm{N}=804$, chi-square, $\mathrm{p}>.05)$, and the cumulative frequency curves stabilized by 100 frames for all substrate types.

C4-C5 was a heterogeneous site (Fig. 4c). Forty percent of the available substrate was sediment, but massive, massive/sediment, and boulders/sediment each contributed more than $10 \%$ of the frames. Enough frames were taken to characterize the site $(\mathrm{N}=810$, chi-square, $\mathrm{p}>.05)$, but the cumulative frequency curves did not level off until 200 frames were analyzed.

The co-dominant substrate types at Pt. Joe were sediment and massive, each contributing $30 \%$ of the analyzed frames (Fig. 4 d). All other substrate types contributed less than $10 \%$ of the frames. The cumulative frequency curves for all substrate types levelled off by 100 frames, and the site was sufficiently sampled $(\mathrm{N}=280)$ to characterize the substrate distributions (chi-square, $p>05$ ). 
Table 3. Preliminary results of video analysis for each site.

\begin{tabular}{|l|c|c|c|c|}
\hline & SOQUEL & CARMEL & C4-C5 & PT. JOE \\
\hline $\begin{array}{l}\text { Number of Frames } \\
\text { Analyzed }\end{array}$ & 323 & 804 & 810 & 280 \\
\hline $\begin{array}{l}\text { Number of Frames } \\
\text { with Rathbunaster } \\
\text { californicus }\end{array}$ & 104 & 11 & 623 & 113 \\
\hline $\begin{array}{l}\text { Actual number of } \\
\text { Rathbunaster californicus }\end{array}$ & 153 & 11 & 1607 & 277 \\
\hline $\begin{array}{l}\text { Number of Substrate Types } \\
\text { Found (out of 17 } \\
\text { combinations) }\end{array}$ & 11 & 11 & 8 & 15 \\
\hline
\end{tabular}




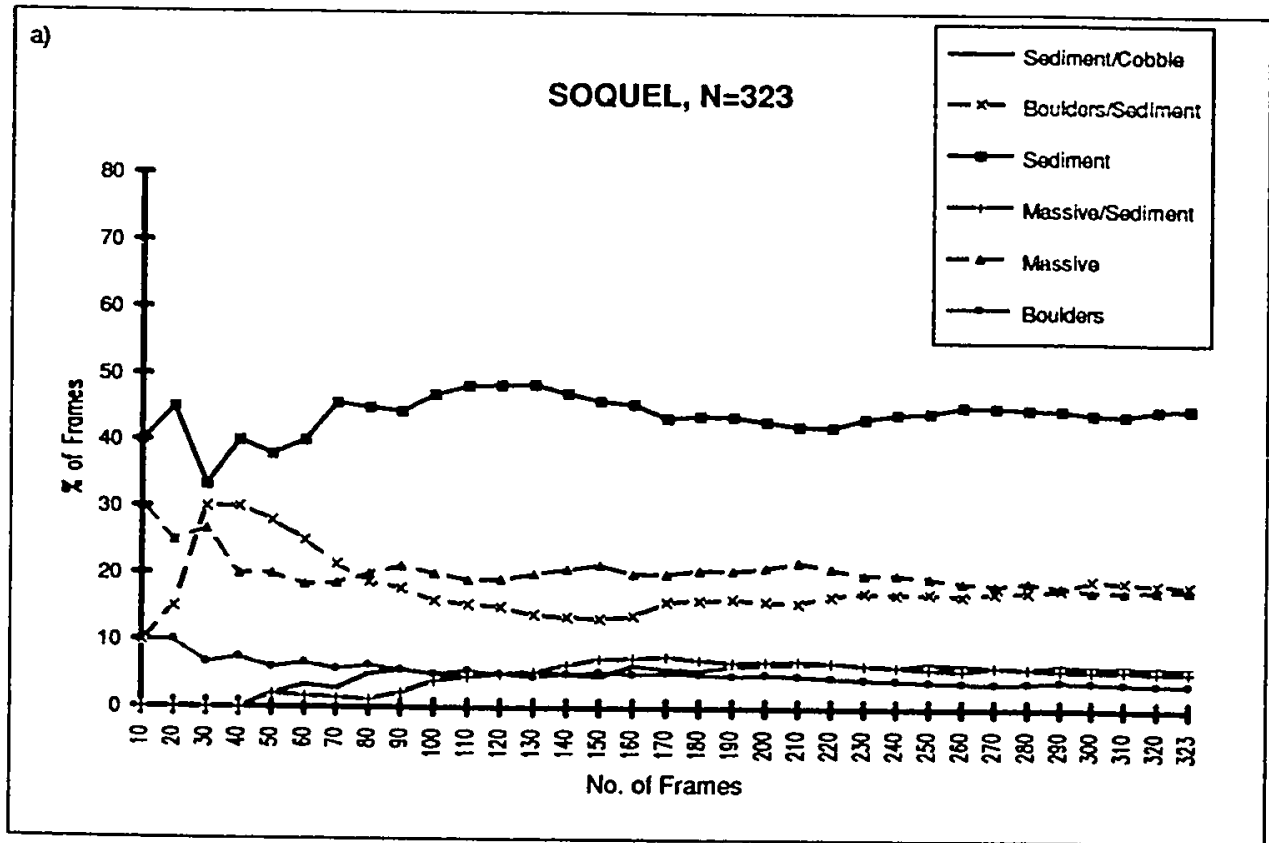

b)

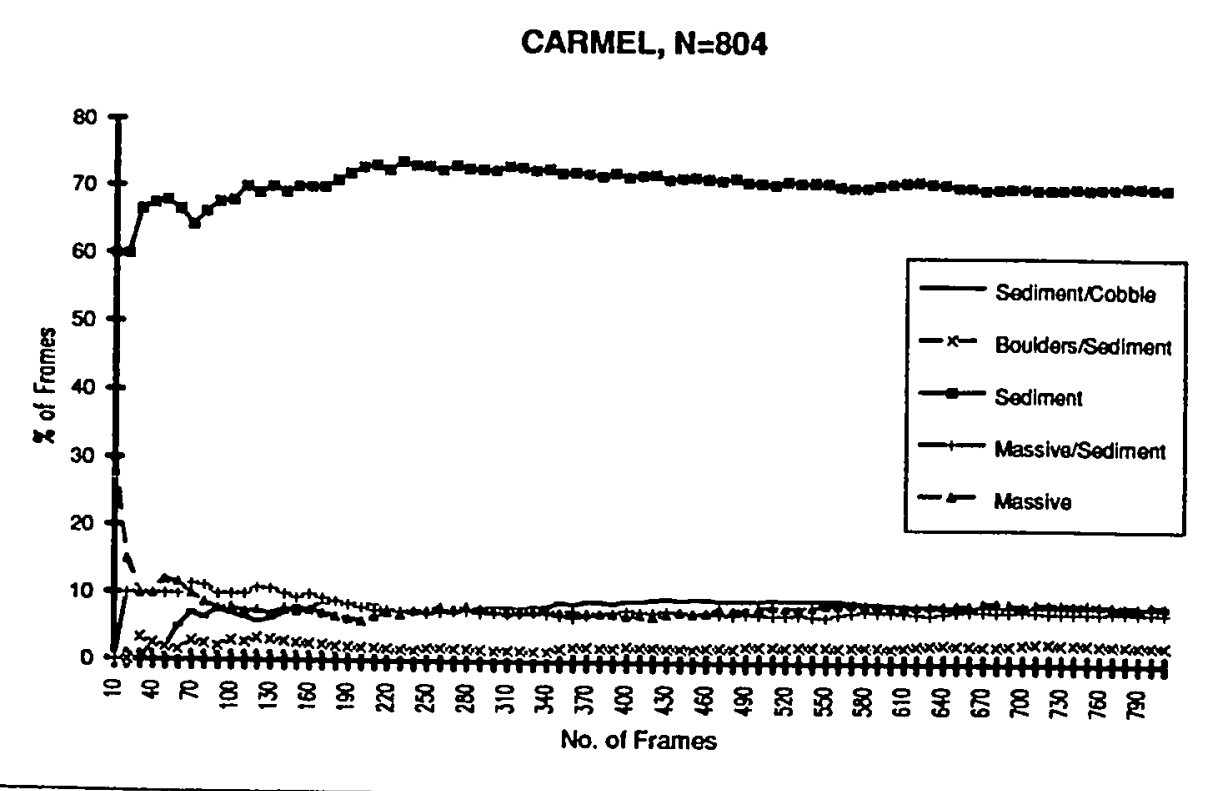

Figure 4. Cumulative frequency curves of most abundant substrate types for each site: a) Soquel, b) Carmel, c) C4-C5, and d) Pt. Joe. $\mathrm{N}=$ total number of video frames analyzed. 


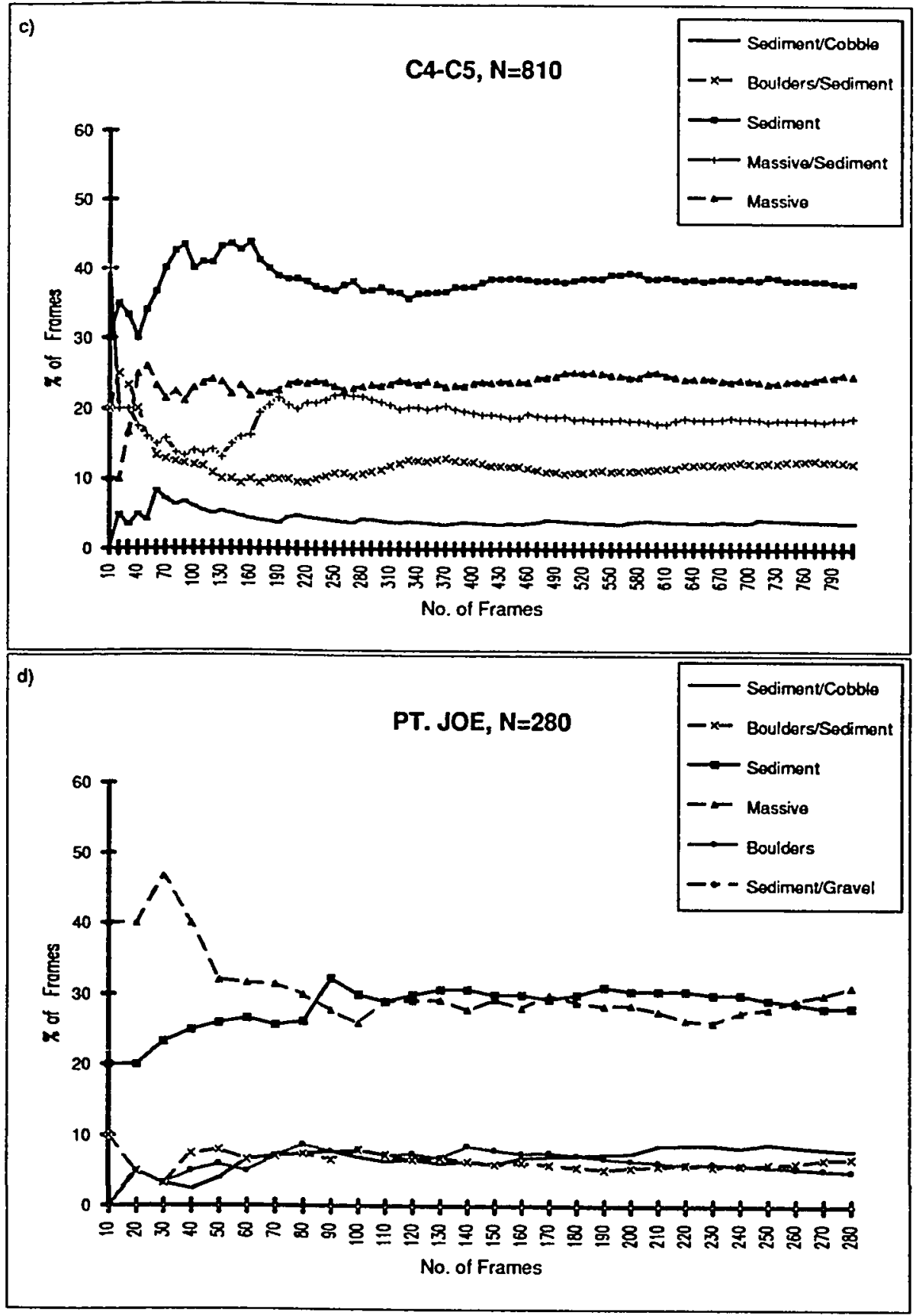

Figure 4. (Continued) Cumulative frequency curves of most abundant substrate types for each site: a) Soquel, b) Carmel, c) C4-C5, and d) Pt. Joe. $\mathrm{N}=$ total number of video frames analyzed. 
When data from Soquel were analyzed to determine how $\underline{\mathrm{R}}$. californicus was distributed relative to substrate types, it was found that frames containing $\underline{R}$. californicus were not distributed in the same proportion as substrate types (Fig. 5a). Frames with $\underline{R}$. californicus were observed a third fewer times in sediment than was expected, and almost twice as many times in boulders/sediment and massive than was expected (chi-square, $\mathrm{p}<.001$ ). Analysis of actual numbers of $\underline{\mathrm{R}}$. californicus yielded an identical pattern.

Carmel was dominated by sediment, but frames containing $\underline{\mathbf{R}}$. californicus were observed less frequently in sediment than expected and more frequently in massive/sediment, boulders/sediment, and boulders/sediment/cobble than expected

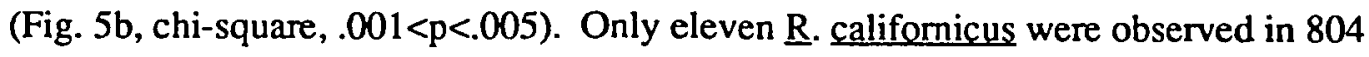
frames. Only one $\underline{R}$. californicus per frame was ever recorded at Carmel, so presence/absence data and actual numbers of seastars/frame were identical.

Frames containing $\underline{\mathrm{R}}$. californicus were distributed in the same proportion as substrate types at C4-C5 (Fig. 5c, chi-square, .10<p<.25). When actual numbers of seastars were analyzed, $\underline{R}$. californicus was found more frequently in sediment than was expected (chi-square, $\mathrm{p}<.001$ ).

Of the two co-dominant substrate types at Pt. Joe, frames containing $\underline{\mathbf{R}}$. californicus were observed more frequently in massive and less frequently in sediment than expected (Fig. 5d, chi-square, p<.001). Frames with $\underline{\mathrm{R}}$. californicus were also found more frequently in massive/sediment, massive/boulders, boulders/sediment, and boulders, and less frequently in sediment/cobble and cobble than was expected. These patterns were also found when actual numbers of $\underline{\mathrm{R}}$. californicus were analyzed.

At the Soquel site, the dominant substrate type in the two deeper intervals was sediment, followed by boulders/sediment and massive (Fig. 6a-b). Rathbunaster californicus was most abundant in boulders/sediment and massive at these depths. 


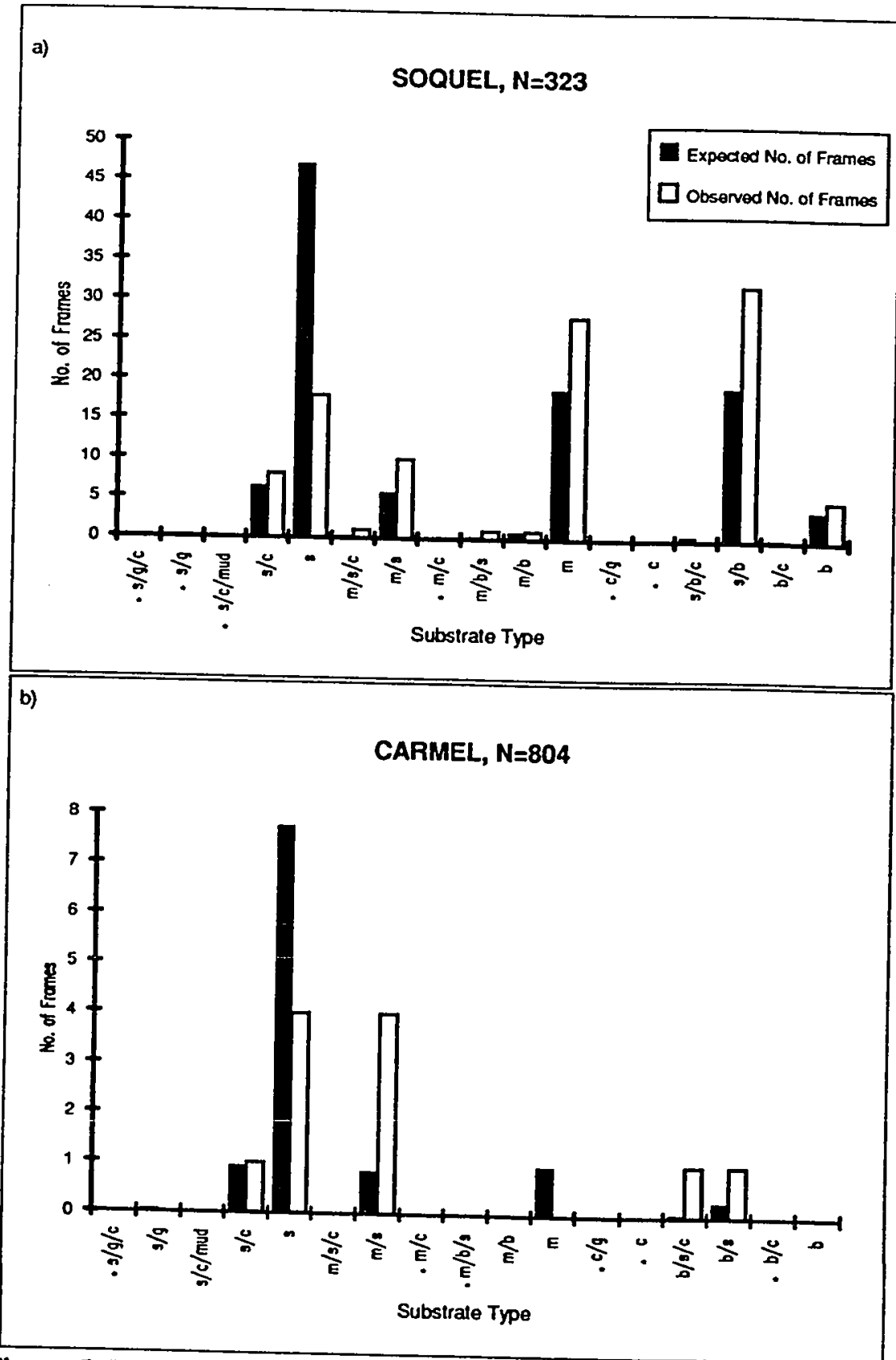

Figure 5. Expected vs. observed number of frames containing Rathbunaster califomicus for each substrate type at a) Soquel, b) Carmel, c) C4-C5, and d) Pt. Joe. $\mathrm{N}=$ total number of video frames analyzed. Abbreviations for substrate types are found in Table 2 . $^{*}=$ these substrate types were not available at a given site, but were included in histograms for comparison between sites. 


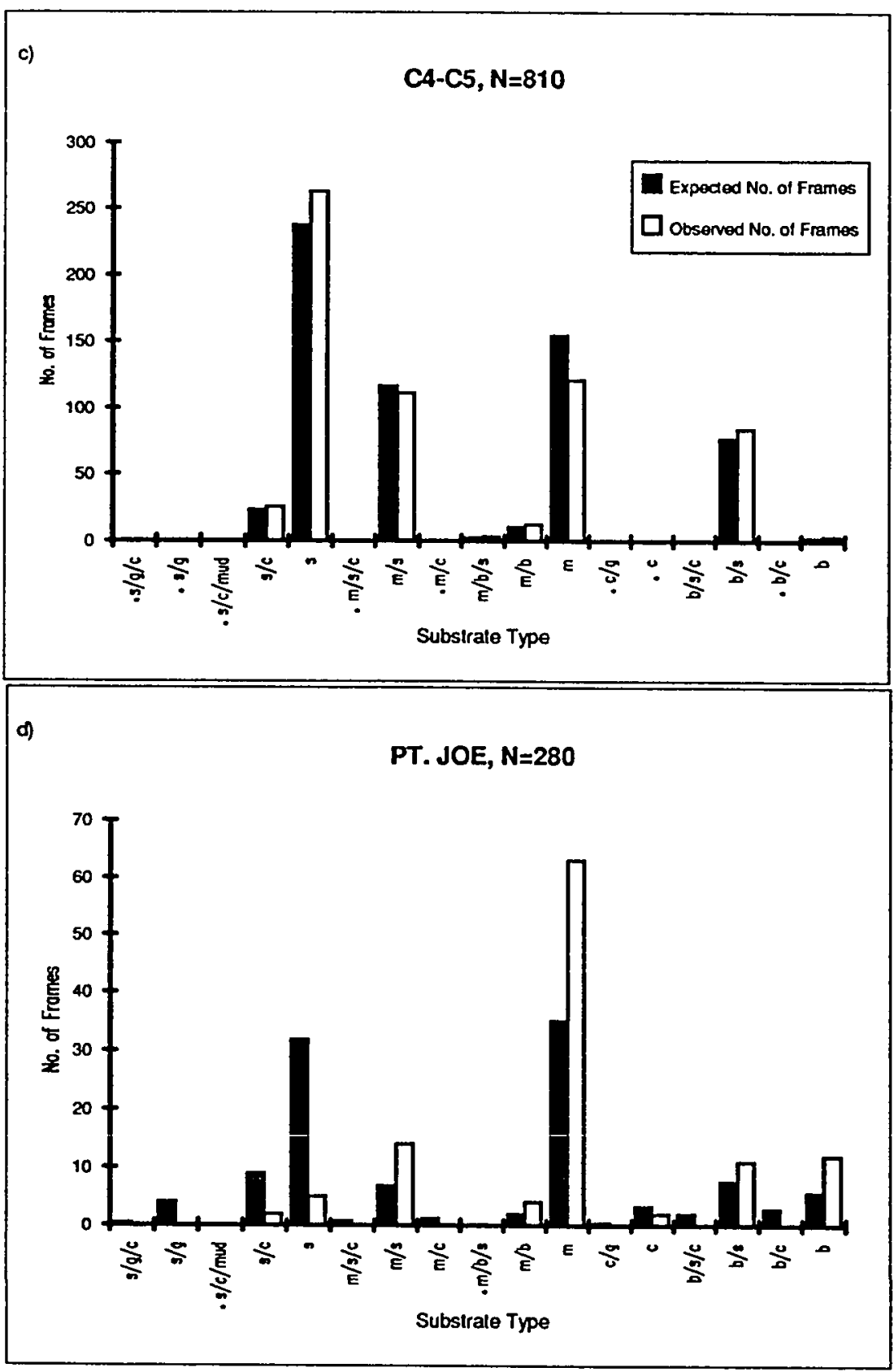

Figure 5. (Continued) Expected vs. observed number of frames containing Rathbunaster californicus for each substrate type at a) Soquel, b) Carmel, c) C4-C5, and d) Pt. Joe. $\mathrm{N}=$ total number of video frames analyzed. Abbreviations for substrate types are found in Table 2 . $^{*}=$ these substrate types were not available at a given site, but were included in histograms for comparison between sites. 
Between 151 and $250 \mathrm{~m}$, boulders/sediment was dominant, followed by massive, sediment, and sediment cobble (Fig. 6 c). In this interval, the greatest number of $\underline{\mathbf{R}}$. californicus was found in sediment.

Sediment substrate was dominant at all depth intervals at Carmel (Fig. 7a-c). Only one $\underline{R}$. californicus was found in the each of the two shallowest intervals. At the deepest interval, between 351 and $450 \mathrm{~m}$, sediment was almost eight times more abundant than massive/sediment, but the same number of seastars were found in both substrate types (Fig. 7c).

At the C4-C5 site, sediment was the most abundant substrate type at both depth intervals, followed by massive/sediment, massive, and boulders/sediment (Fig. 8a-b). In both intervals, $\underline{\mathrm{R}}$. californicus was found most frequently in sediment substrate and least often in massive terrain.

At Pt. Joe, percentages of substrate types varied between $50 \mathrm{~m}$ to $450 \mathrm{~m}$ (Fig. 9a-d). Sediment was the dominant substrate type in the shallowest three intervals, where very few $\underline{\mathrm{R}}$. califormicus were seen. Rathbunaster californicus was only abundant in the deepest interval, where massive substrate was dominant (Fig. 9d).

Sponges, holothuroids, rockfish, the urchin Allocentrotus fragilis, and other seastars occurred most frequently in the frames containing $\underline{R}$. californicus at Soquel

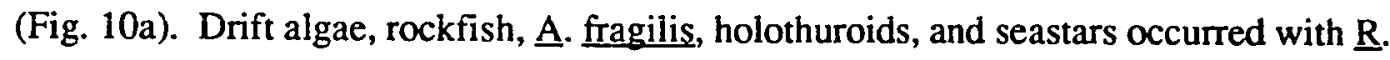
californicus (Fig. 10b) at Carmel. The same organisms found at Soquel were found at C4-C5 (Fig. 10c). Sponges, rockfish, seastars, and A. fragilis most frequently cooccurred with $\underline{\mathrm{R}}$. californicus at Pt. Joe (Fig. 10d).

The Soquel and C4-C5 sites had the most similar assemblages of organisms associated with $\underline{\mathrm{R}}$. californicus (PSI $=86 \%$ ) and the most similar arrays of available substrate types (PSI=79\%, Table 4). C4-C5 and Pt. Joe were the next most similar in both analyses (72\% and $73 \%$ respectively), followed by Soquel and Pt. Joe (70\%, $71 \%)$. 


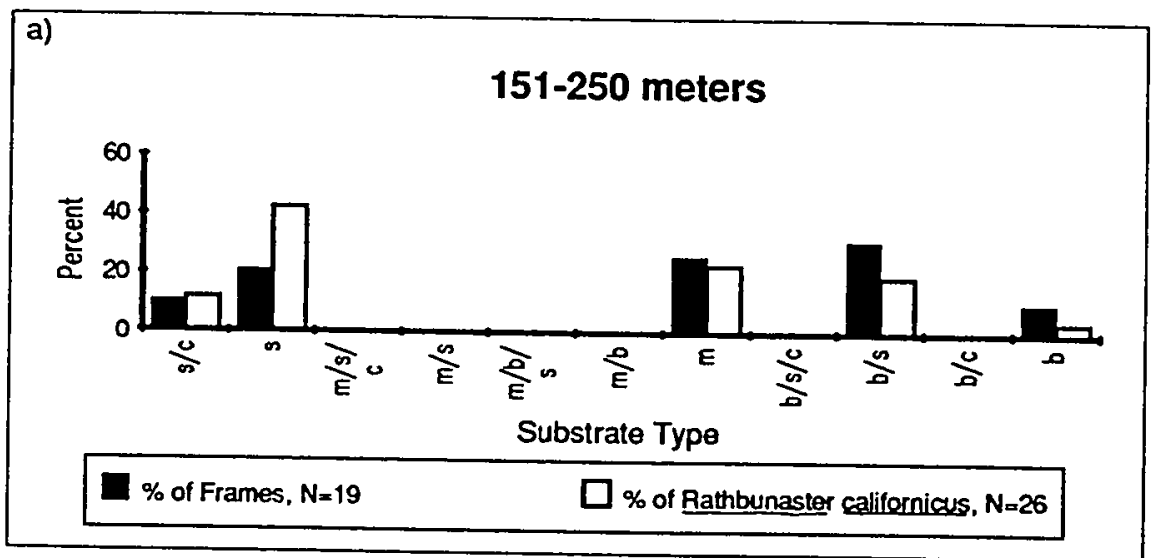

b)

\section{1-350 meters}
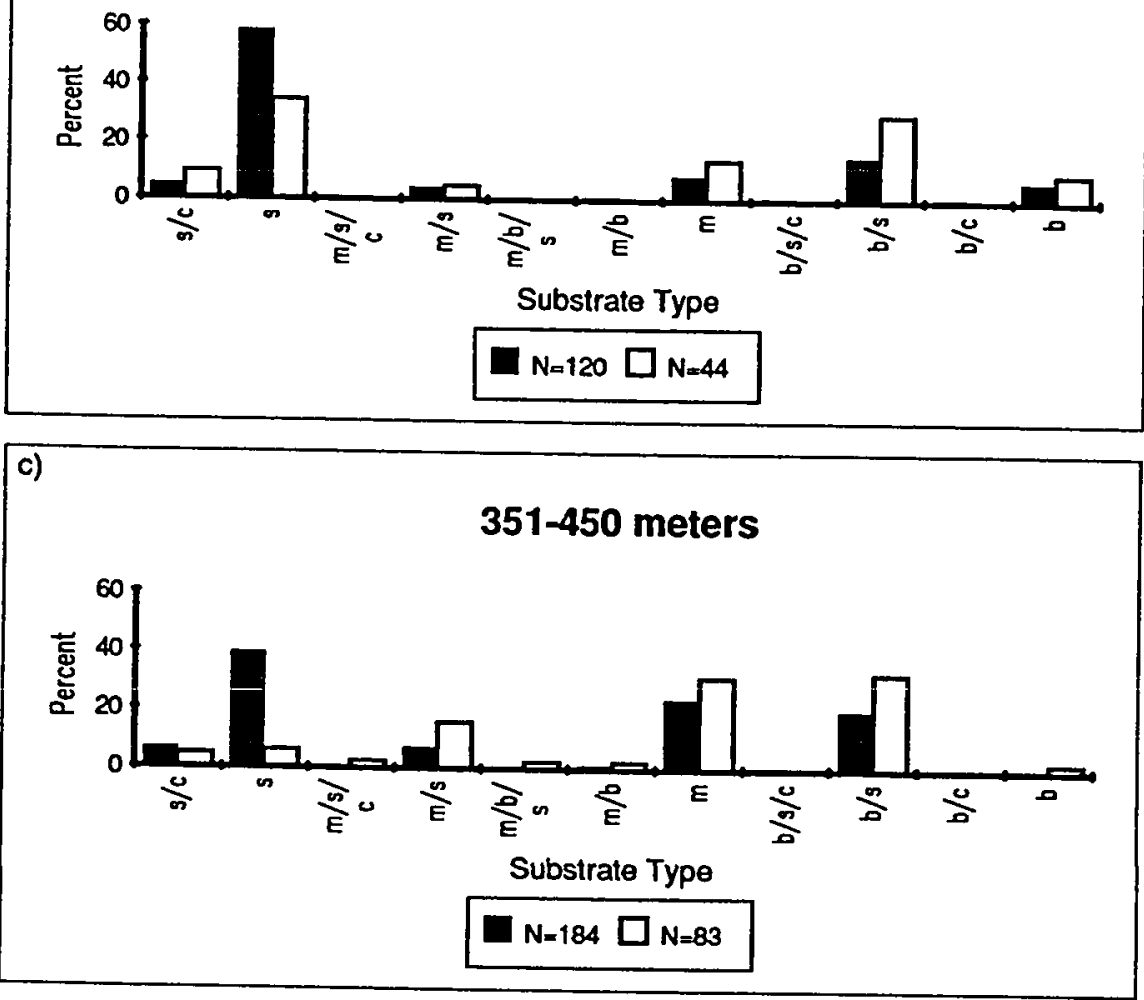

Figure 6. Comparison of percent of Rathbunaster califomicus observed with percent of frames for each substrate type at the Soquel site from: a) $151 \mathrm{~m}$ to $250 \mathrm{~m}$, b) $251 \mathrm{~m}$ to $350 \mathrm{~m}$, and c) $351 \mathrm{~m}$ to $450 \mathrm{~m}$. $\mathrm{N}=$ total number of variable in question. Abbreviations for substrate types are found in Table 2. 

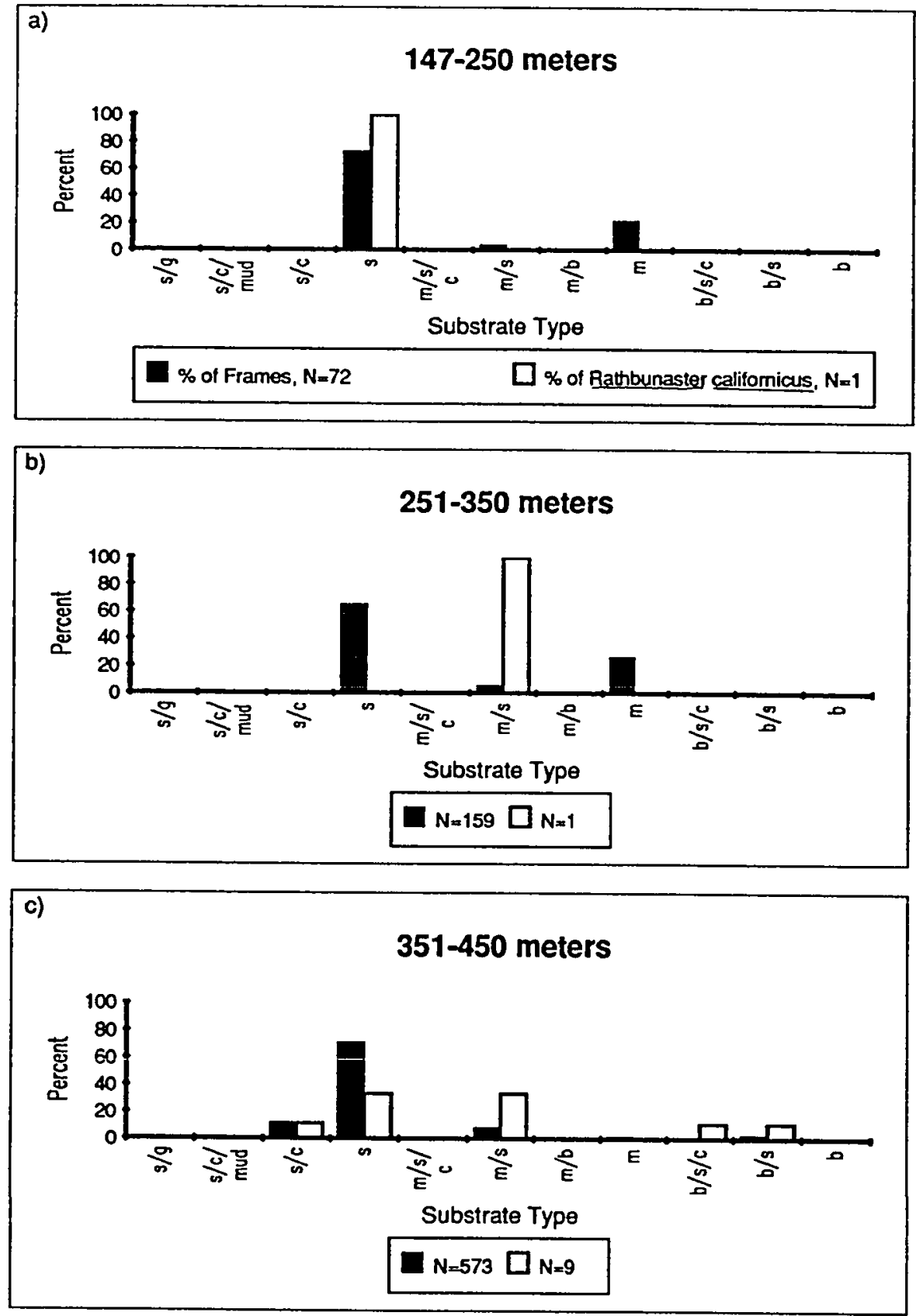

Figure 7. Comparison of percent of Rathbunaster californicus observed with percent of frames for each substrate type at the Carmel site from: a) $147 \mathrm{~m}$ to $250 \mathrm{~m}$, b) $251 \mathrm{~m}$ to $350 \mathrm{~m}$, and c) $351 \mathrm{~m}$ to $450 \mathrm{~m}$. $\mathrm{N}=$ total number of variable in question. Abbreviations for substrate types are found in Table 2. 
a)
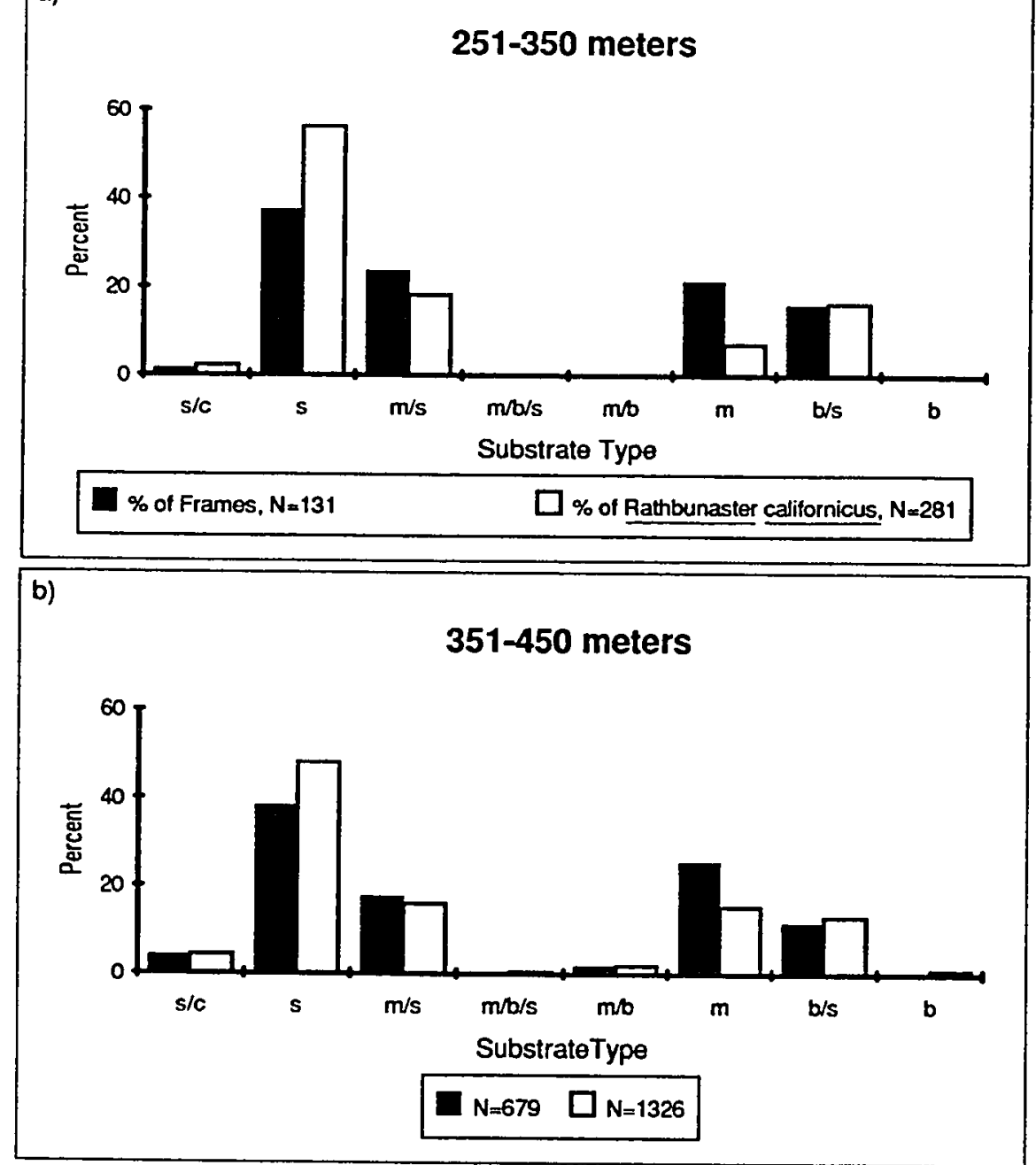

Figure 8. Comparison of percent of Rathbunaster californicus observed with percent of frames for each substrate type at the C4-C5 site from: a) $251 \mathrm{~m}$ to $350 \mathrm{~m}$ and b) $351 \mathrm{~m}$ to $450 \mathrm{~m}$. N=total number of variable in question. Abbreviations for substrate types are found in Table 2. 

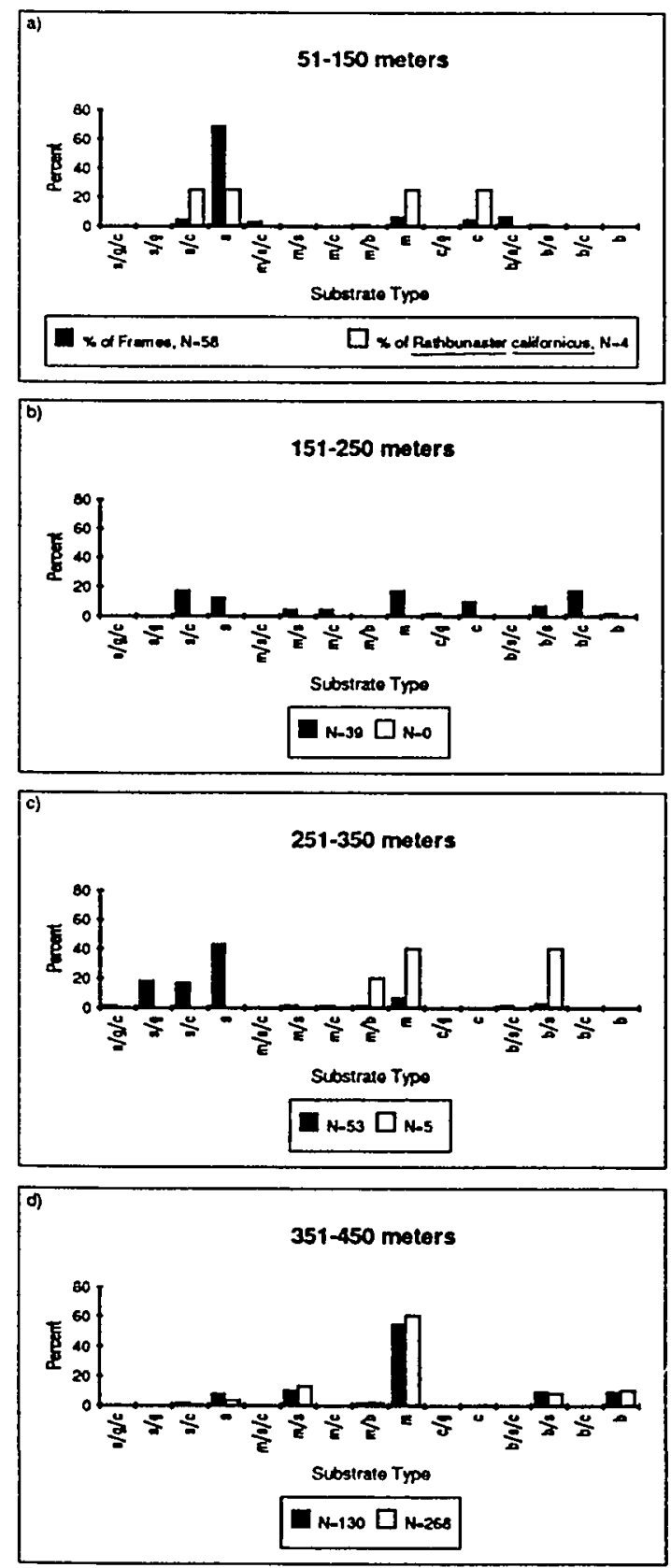

Figure 9. Comparison of percent of Rathbunaster californicus observed with percent of frames for each substrate type at the Pt. Joe site from:

a) $51 \mathrm{~m}$ to $150 \mathrm{~m}$, b) $151 \mathrm{~m}$ to $250 \mathrm{~m}$, and c) $251 \mathrm{~m}$ to $350 \mathrm{~m}$, and d) $351 \mathrm{~m}$ to $450 \mathrm{~m}$. N=total number of variable in question.

Abbreviations for substrate types are found in Table 2. 


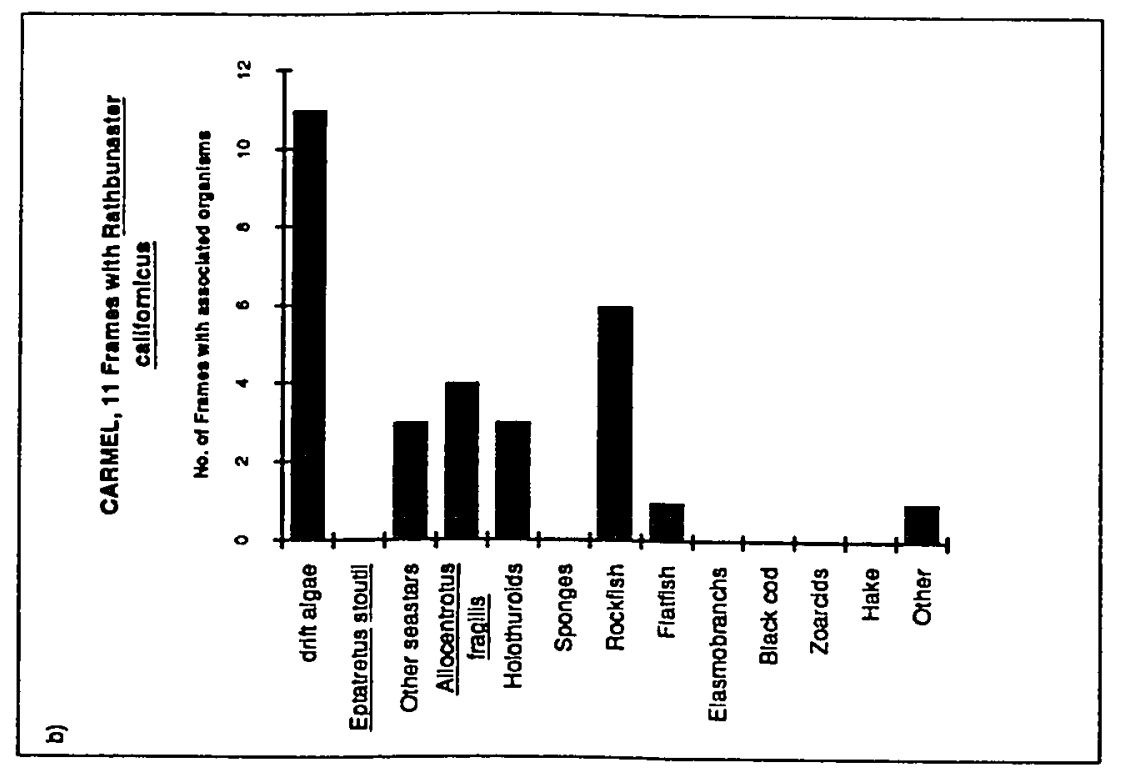

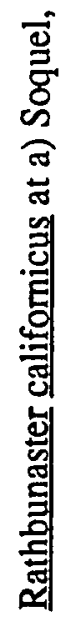

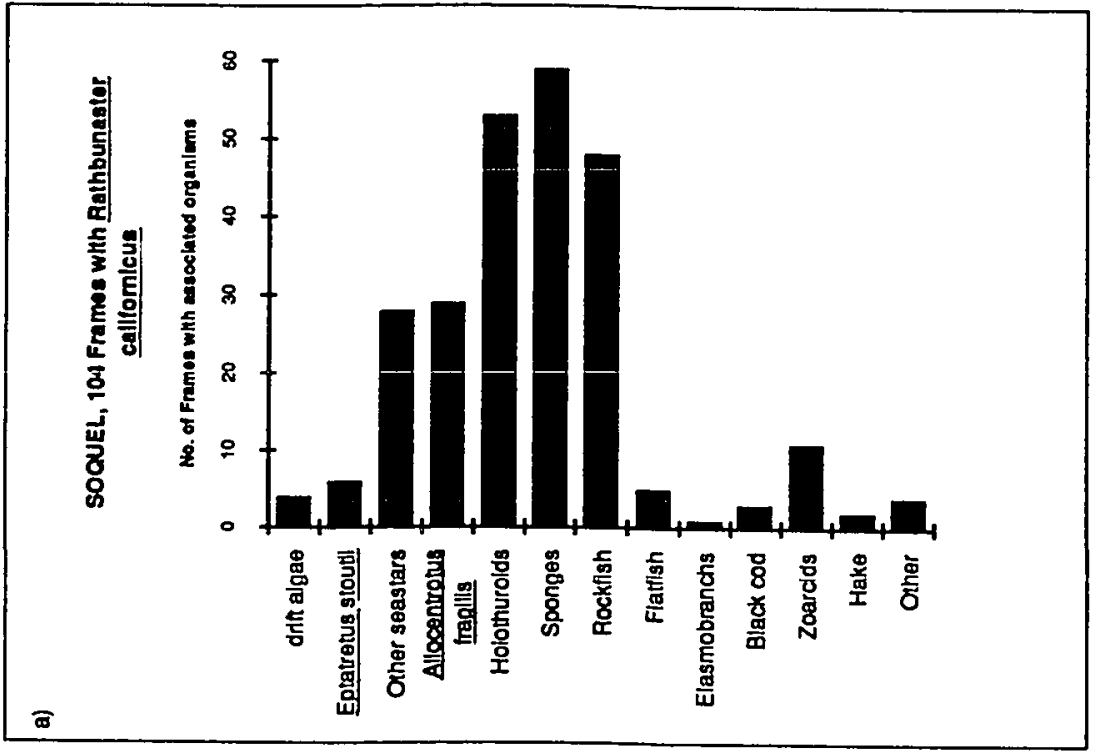

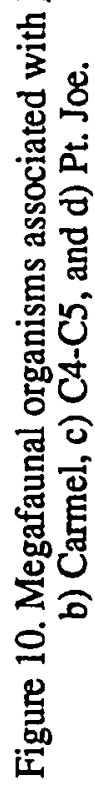




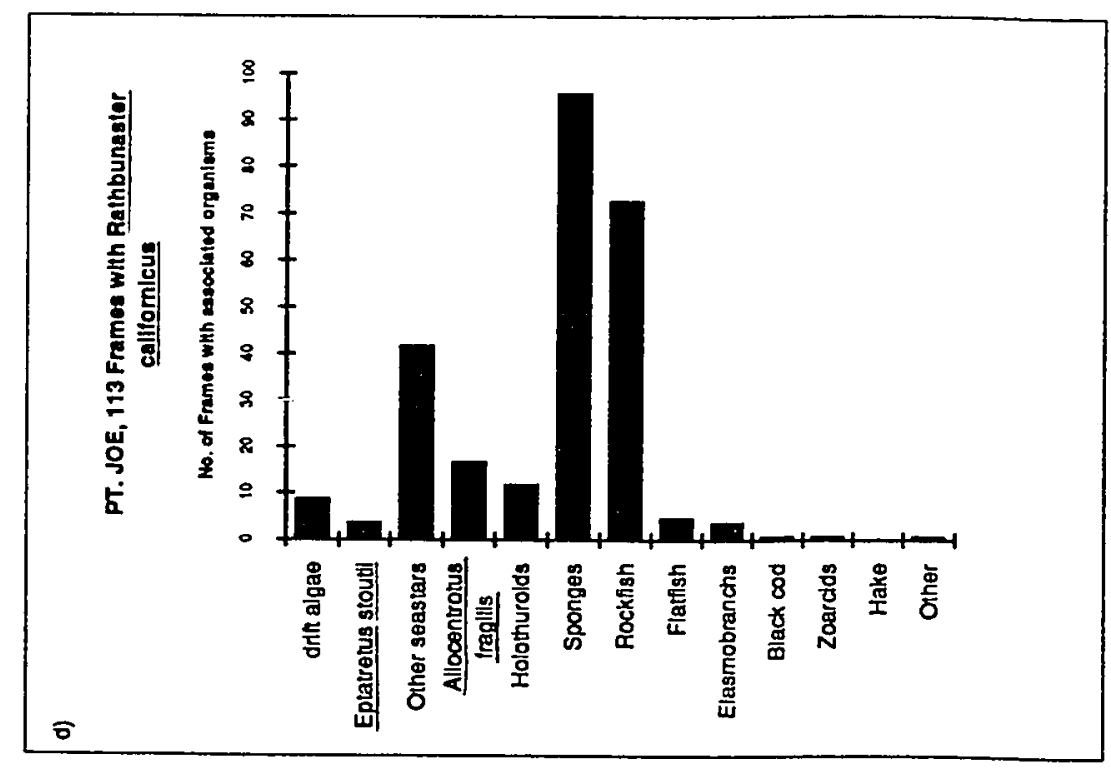

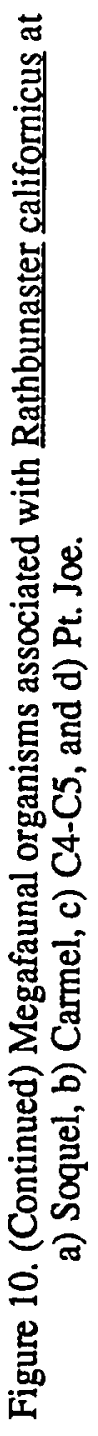


Table 4. Percent Similarity Indices (PSI) showing degree of similarity of associated organism taxa and substrate types among sites.

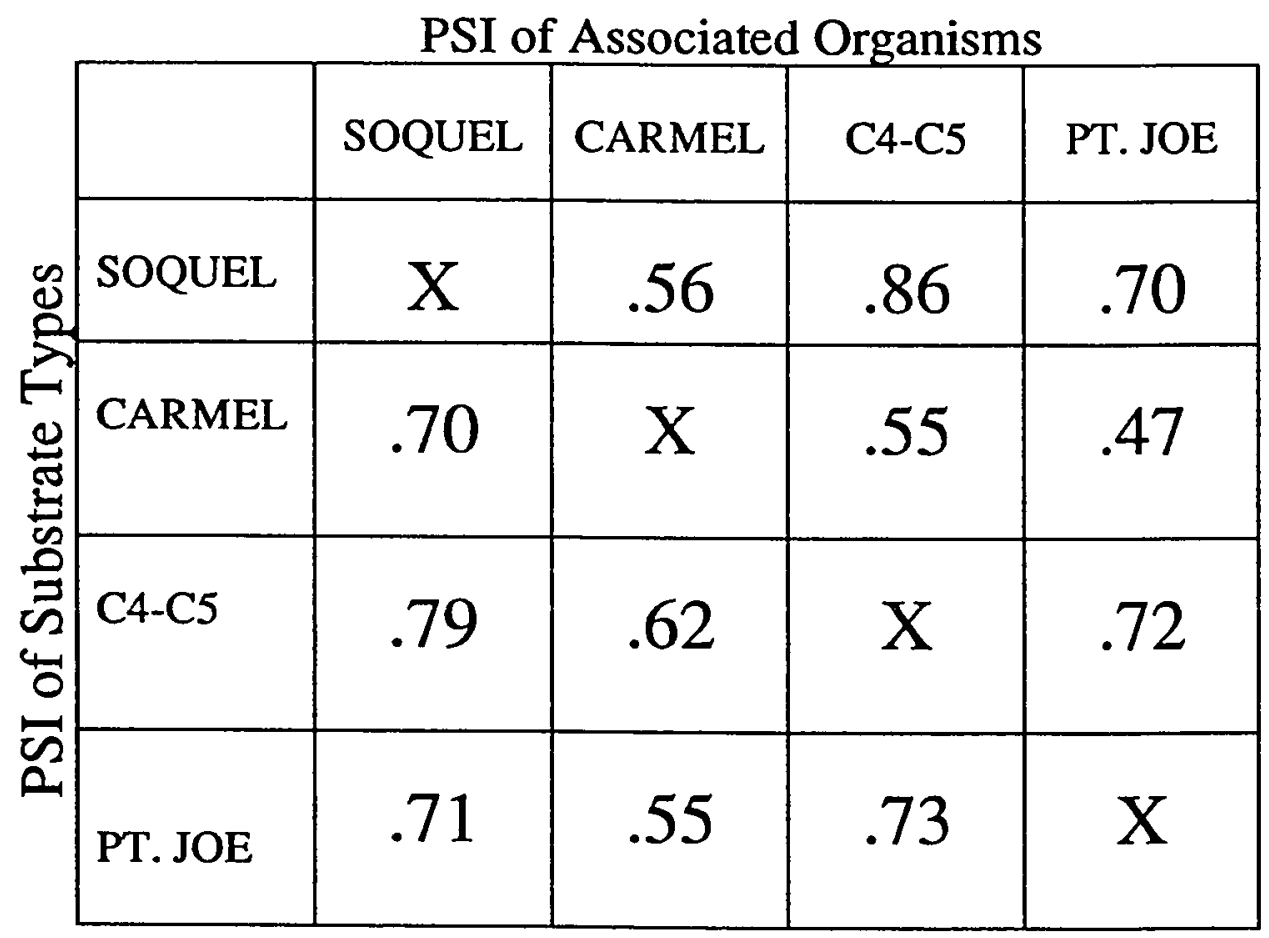


Carmel was most similar to Soquel, with a PSI of $56 \%$ for associated organisms and 70\% for substrate types.

\section{DISCUSSION}

Patterns of substrate use by Rathbunaster californicus seem to vary among the four sites, and in some cases, from depth to depth within sites. The observed differences in habitat use among sites may be due to location of the sites in the canyon relative to currents and other physical factors, which in turn may affect what types of substrate are available. Sediment was abundant at all four sites, but the proportion of massive and boulders was very different between sites. Differences in habitat use within sites may also reflect availability of habitats as a function of depth.

Overall, it is only possible to generalize about $\underline{\mathbf{R}}$. californicus habitat use within a particular site. At Soquel, $\underline{\mathbf{R}}$. californicus was observed more frequently in rough terrain and less on sediment than was expected. This also was observed at Carmel. Frames containing $\underline{\mathrm{R}}$. californicus at $\mathrm{C} 4-\mathrm{C} 5$ were distributed in the same proportion as substrate types, but analysis of actual numbers of seastars indicated that they were more numerous on sediment substrate than was expected. At Pt. Joe, $\underline{\mathbf{R}}$ californicus were distributed in the same proportion as the substrate types. Data on presence/absence, actual numbers of animals, and depth intervals were all necessary to interpret the observed patterns of habitat use. Use of only one type of data could have led to misinterpretation of the data.

For example, Rathbunaster californicus at Soquel was found more frequently in rough terrain than in smooth terrain. In the two deeper intervals, $\underline{R}$. californicus was most abundant in massive and boulders/sediment substrate, even though these substrate types were far less available than sediment (Fig. 6). However, the abundance of $\underline{R}$. californicus on sediment substrate in the $150 \mathrm{~m}$ to $250 \mathrm{~m}$ interval at Soquel was 
inconsistent with the general pattern of substrate use at this site. This discrepancy may have been a result of a large patch of animals encountered in a few frames. Eleven of the $26 \underline{\mathrm{R}}$. californicus were found in three frames out of four taken in sediment. In addition, sample size was low in this depth interval; only nineteen frames were analyzed. The four dives at Soquel were spread out horizontally over several thousand meters, and some did not occur in the head of the canyon, as did all of the dives at Carmel. Soquel, however, was considered an axis site because relative to $\mathrm{C} 4-\mathrm{C} 5$ and Pt. Joe, the dives occurred near the dead-end of the canyon.

The Carmel site was very different than the other three sites. The reasons for use of hard substrate by $\underline{\mathrm{R}}$. californicus at this site may be different than at Soquel due to the dynamics of the axis environment. Most of the dive time at Carmel was spent transecting in the axis of the canyon. The axis substrate consisted mostly of sediment (70\% of frames analyzed). The same number of $\underline{\mathrm{R}}$. californicus found in sediment frames was found in the eight percent of frames containing massive/sediment. This may indicate a true affinity for hard substrate, but more likely reflects an inability to survive in the axis where strong currents can scour the substrate and roll animals downcurrent (pers. obs.). These conditions may explain why only eleven $\underline{\mathbf{R}}$. californicus were found in the 804 frames from Carmel.

Analysis of presence/absence data at $\mathrm{C} 4-\mathrm{C5}$ indicated that $\underline{\mathrm{R}}$. californicus was distributed statistically in the same proportion as the available substrate types (Fig. 5a). Analysis of actual numbers of seastars per substrate type indicated that $\underline{\mathbf{R}}$. californicus was more abundant in soft sediment slope environments than in rough terrain (Fig. 8). The discrepancy between the two types of data indicates that at this site, large aggregates of $\underline{\mathrm{R}}$. californicus occurred on the sediment slopes. The greater occurrence and increased numbers of $\underline{\mathrm{R}}$. californicus at $\mathrm{C} 4-\mathrm{C} 5$ may be related to the stepped nature of the terrain. At this site, large sediment patches were often surrounded by massive 
wall structures unseen in the frame. Rathbunaster californicus has been observed to be a mobile, often fast-moving animal and if hard or soft substrate is important to this seastar's survival, either may be easy to find in this stepped, heterogeneous environment.

At Pt. Joe, initial chi-square analysis of presence/absence data and actual numbers of $\underline{\mathbf{R}}$. californicus indicated that $\underline{\mathrm{R}}$. californicus was found more frequently on hard substrate and less often on soft substrate than was expected (Fig. 5d). However, $\underline{\mathbf{R}}$. californicus was observed in very low numbers at all but the deepest depth interval (Fig. 9d). The three shallower intervals contained only nine $\underline{R}$. califormicus, but also contained $86 \%$ of the sediment frames. Inclusion of these data in the initial analysis biased the results to show an affinity for hard substrate. At Pt. Joe, $\underline{R}$. californicus was not found often in shallow water. In deep water, $\underline{\mathbf{R}}$. californicus was found most frequently in hard substrate, which was the most abundant type.

The use of rough substrates by $\underline{\mathbf{R}}$. californicus seen at Soquel, Carmel, and Pt. Joe could be to avoid being dislodged by currents. Slight turbulence caused by ROV thrusters can send $\underline{\mathbf{R}}$. californicus down-canyon (pers. obs.). If predation on $\underline{\mathbf{R}}$. californicus occurs, geologic relief could provide refuge. Current direction and speed vary within the canyon and may affect transport of food and the dispersal of $\underline{\mathbf{R}}$. californicus larvae. Rough terrain could be a sink for large nekton falls (Smith, 1985), or it could be a necessary substrate for settlement of $\underline{R}$. californicus larvae. The more frequent use of hard substrate at the two axis sites could also be related to unidentified physical factors related to axis dynamics.

Superficial observations indicated that $\underline{\mathbf{R}}$. californicus was found in patches. Patchiness might be of biological significance to the seastar, but presence/absence analysis did not yield such information. Because area covered was not known, estimates of dispersion could not be made. However, comparison of number of frames 
containing $\underline{\mathrm{R}}$. californicus and actual number of $\underline{\mathrm{R}}$. californicus per frame allowed large scale trends to be extracted. Large numbers of seastars in only a few frames could change the patterns of more frequent use of hard substrates or proportional use of substrates. This was not the case at Carmel and Pt. Joe, and patterns of $\underline{\mathrm{R}}$. californicus habitat use did not change between analyses. At $\mathrm{C} 4-\mathrm{C} 5$, patterns did change from proportional habitat use to affinity for sediment, and in the shallower areas of Soquel, patches of $\underline{R}$. californicus were found. Analysis of actual numbers of organisms illustrated patterns that presence/absence data alone missed.

Rathbunaster californicus occurred at all four sites with similar arrays of associated megafauna. The common associated fauna included mobile organisms such as rockfish, urchins (Allocentrotus fragilis), holothurians, and seastars. Sponges cooccurred at all sites except Carmel, and drift algae occurred with $\underline{\mathrm{R}}$. californicus only at Carmel. Mobile organisms have more control over their interactions than do their sessile counterparts. The mobility of $\underline{\mathrm{R}}$. californicus is intermediate between that of the associated fishes and the sessile invertebrate community. Rathbunaster califormicus could be competing with the mobile organisms for prey items and with the sessile organisms for space and food. It also could be prey for the mobile organisms, prey on the sessile organisms, and provide prey, in the form of eggs and larvae, to the sessile organisms. Too little is known about the natural history of these animals to assign biological meaning from these assemblages.

Soquel and C4-C5 had the highest percent similarity, both by associated organisms and by availability of substrate types (Table 4). The $\underline{R}$. californicus at these two sites exhibited opposite affinities, for hard substrate at Soquel and soft substrate at C4-C5. The same proportional availability of substrate types and associated organisms may indicate that other parameters not identified in this study affect $\underline{\mathbf{R}}$. californicus distribution. Pt. Joe and C4-C5 were also similar in both analyses. Both sites were 
located along a steep canyon wall, and the observed similarity was not surprising. Pt. Joe and Soquel were also similar in both arrays. Carmel was most similar to Soquel in both analyses, and this may be related to the proximity of both sites to a canyon axis. However, the similarity between arrays of organisms at these two sites was low (PSI $=56 \%$ ), indicating organisms react to the differences between sites despite the similarity of available substrate types. Overall, there were relatively few organisms found at Carmel, and this might have been observed at Soquel had all the dives occurred directly in the canyon axis. The relatively high values for all sites compared to Carmel were due to the high percentage of sediment substrate found at every site. Overall, however, Carmel was the least similar to all other sites, as was expected.

There were several potential problems with the methods used. Standardized video transects were not available, and video data were recorded during dives operated under different dive plans. This bias should be partially eliminated because frames were never overlapping, effectively only using data points when the ROV was in motion and thereby simulating a transect. One of the boxes at $\mathrm{C} 4-\mathrm{C} 5$, used to show area of the canyon visited, was exceptionally large (Fig. 2), indicating erroneous data points in that day's navigation data set. Overall, however, the boxes were adequate to graphically represent where the four dive sites were located. While sample sizes were statistically more than adequate to describe the distribution of substrate types at each site, the distances between the four dives at Soquel limited the ability to generalize about spatial patterns at this site.

The subjective assignment of habitat descriptors to frames was another source of bias in the sample design. Differences between expected and observed number of frames containing $\underline{R}$. californicus for each substrate type (Fig. 5a-d) may be statistically unsound due to small sample sizes in some substrate categories (Zar, 1974). According to Cochran (1954), no expected frequency should be less than 1.0 , and no more than 
$20 \%$ of the expected frequencies should be less than 5.0, in order to maximize the power of the test. This rule was violated in our analysis. By lumping data points into large categories such as sediment, massive, or boulders, it was possible to eliminate this problem. However, this type of study necessarily assumes that the resource states recognized by the ecologist are the same as those recognized by the organism (Krebs, 1989); by reducing the number of substrate types used in analysis, the probability that this assumption was correct may have been decreased. When data were lumped into broad categories and analyzed by chi-square, expected and observed values at C4-C5 became statistically significant $(\alpha=.05)$. This result differed from analysis using all eight substrate types, and it is unclear which, if either, reflects biological reality for the seastar. By plotting expected vs. observed number of frames containing $\underline{R}$. californicus and analyzing the large scale trends, these problems were adequately circumvented.

Of the habitat descriptors (Table 1), only combinations of substrate type were used for analysis (Table 2). The number of combinations of descriptors from all five categories was too large to analyze by these methods. Sample sizes for all combinations would have been very low in most categories. The other habitat categories, however, might affect average current velocity, distribution of other fauna, and composition of the benthopelagic layer, which may in tum affect distribution of $\underline{R}$. californicus. Rathbunaster califomicus may recognize more detailed combinations of habitat descriptors, and reanalysis using multivariate techniques might be useful for future work.

Detailed quantitative analysis of video did not substantiate for all sites the initial hypothesis that $\underline{\mathrm{R}}$. californicus was observed more frequently on soft sediment slopes. There were variations between sites and depths in which substrate types were available and which were used, and $\underline{R}$. californicus habitat use appeared to reflect these differences. At Soquel and Carmel, $\underline{\mathrm{R}}$. californicus was most abundant on hard 
substrates. At Pt. Joe, $\underline{\mathrm{R}}$. califormicus was found in the same proportion as the substrate types. Only at C4-C5 and in shallow areas at Soquel was there a bias towards use of soft substrate. The discrepancy between intuitive patterns and actual trends may in part be attributed to superficial assignment of sediment patches covered with cobble or gravel, or mixed in amongst boulders or massive features, to the sediment slope substrate. Only with close analysis were such details extracted.

Now that general patterns of substrate use have been documented, testable hypotheses can be generated and experimentation is warranted. For example, the strength of the association of $\underline{\mathrm{R}}$. californicus with rough terrain at Soquel and Carmel should be tested by tagging individuals, moving them to different substrate types, and monitoring their movement to see if they migrate back to rough terrain. Time should be spent searching rocky terrain for juvenile seastars. These are seldom seen, and may be hidden from wide-angle view. Finally, larval settlement plates should be monitored in both rough and smooth terrain to see if $\underline{\mathbf{R}}$. californicus larvae are present more often in rocky areas. 


\section{DIET AND FEEDING BEHAVIOR OF RATHBUNASTER CALIFQRNICUS IN MONTEREY BAY}

\section{INTRODUCTION}

To determine the effect of predation by an organism on its community requires well designed experiments that consider both availability of prey as well as prey and predator distribution (Menge, 1972b; Annett and Pierotti, 1984). However, even determining what an organism eats can be difficult. Prey items are found in varying degrees of decomposition due to digestion, making identification challenging. True composition of diet may be underestimated because of different handling times of prey items (Fairweather and Underwood, 1983). Those items that take a long time to digest might be over-represented, while items without hard parts or those that are easily digested might be underestimated or missing from analysis completely. Most seastars feed extraorally, so that stomach contents alone are questionable for determining their diet (Jangoux, 1982). In addition, some organisms feed on a tidal or seasonal cycle, and the complete feeding cycle must be examined to accurately describe the total diet. Diets determined from trawl specimens also may be unreliable because feeding may occur while in the nets. The combination of field observation, laboratory observation, and analysis of a large number of stomach contents is the most reliable method of determining the diet of a species or population (Carey, 1972). Even after the diet of an organism is determined confidently from one location, the ability to generalize to other locations can be limited (Fox and Morrow, 1981).

The predatory role of seastars in community organization is known primarily from intertidal and shallow subtidal areas. In general, seastars are successful opportunistic predators. Seastars can feed by eversion of the stomach, ingestion of prey into the stomach, flagellary-mucus feeding on suspended material, or combinations of 
these (Jangoux, 1982). Asteroids exhibit dietary specialization and trophic opportunism (Jangoux, 1982). The main food resources of most asteroids are live mobile or sessile animals (Jangoux, 1982), but some exhibit facultative necrophagy (Arnaud, 1970) and a few can capture highly mobile swimming prey (Dearborn, 1977; Dearborn et al., 1981). Many show intraspecific feeding diversity and are fundamentally polytrophic (Jangoux, 1982).

There is little information concerning $\mathrm{R}$. californicus feeding habits (Table 4).

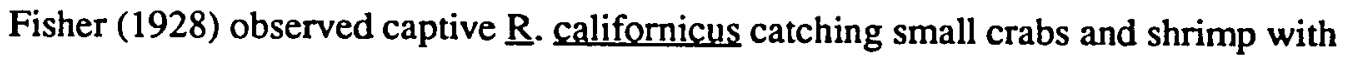
crossed pedicellariae and tube feet. Carey (1972) found echinoid and crustacean fragments in the stomach of one of two $\underline{R}$. californicus specimens trawled off of Oregon, but this record could be biased by net feeding. Review of the feeding habits of related species indicates a variety of diets and feeding mechanisms (Table 5). The diet of Pycnopodia helianthoides has been especially well documented (Table 5), and the variation in diet between study sites indicates the limited ability to generalize about seastar diet over large geographical areas.

Based on the diet and feeding methods of related species, limited literature on the diet of $\underline{\mathbf{R}}$. californicus, and in situ observations, it was hypothesized that $\underline{\mathbf{R}}$. californicus was both a predator and a scavenger, that could use pedicellariae, arms, and tube feet to capture large organisms from the benthic-water column interface. The objectives of this part of the study were to determine the diet of $\underline{R}$. californicus at two sites in Monterey Bay and to describe feeding behavior.

\section{MATERIALS AND METHODS}

Between June 1990 and October 1991, specimens of Rathbunaster californicus were collected from the Soquel and C4-C5 sites (Fig. 2) for stomach content analysis. Samples were collected with the ROV manipulator arm or with a suction device, 


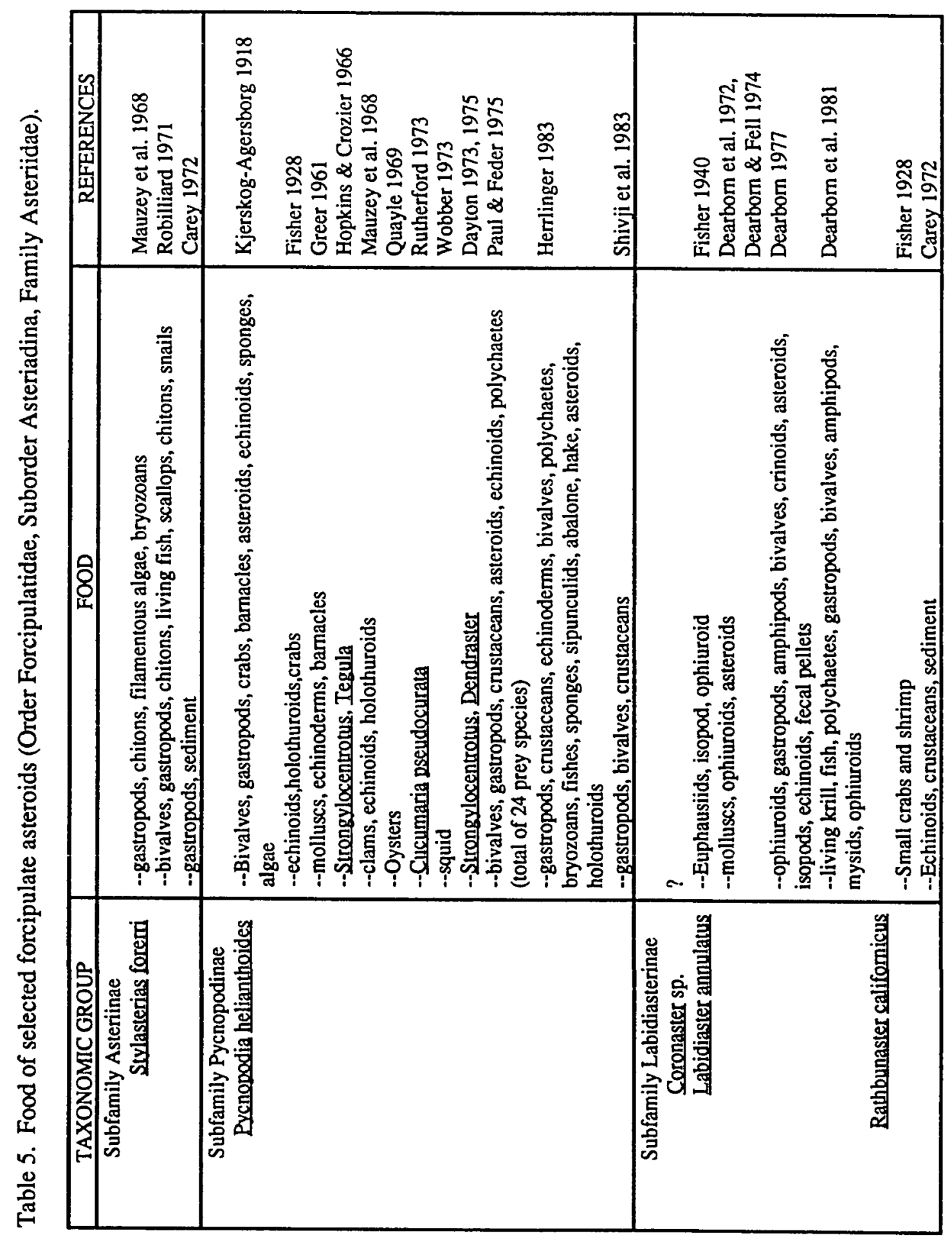


deposited into a hydraulically opening and closing drawer, and brought to the surface in a volume of sea-water at the ambient temperature of collection depth. Specimens were then placed in individual jars. Concentrated $37 \%$ formalin was injected into each stomach to stop digestion of prey items, and the whole animal was fixed in $10 \%$ buffered formalin for at least ten days. Specimens were transferred to $70 \%$ ethanol for long-term storage.

The arms of the fixed specimens were often curled around the mouth and disc, so they were detached from the disc to facilitate the search for prey items in the stomach. All potential prey items found in the storage jar were transferred to a jar reserved for incidental prey items. These may have been regurgitated during transit or fixation, or may have fallen off of the arms. Prey items were either picked out of the stomach folds through the mouth opening on the oral surface or through incisions on the aboral surface. All prey items extracted from one stomach were stored together in $50 \%$ ethanol. The stomach folds and disc were then washed with water. Any prey items or pieces retrieved in this wash were stored in the "incidental" jar. The prey items extracted and divided into "gut contents" and "incidental" categories were identified to the lowest possible taxa. A list of food items was generated, and percentage of $\underline{\mathbf{R}}$. californicus containing prey types were calculated for gut contents and incidental categories using all dissected stomachs from each site. Food items were plotted against percent frequency of occurrence to compare gut contents and incidental items within each site and between sites.

Feeding behavior of $\underline{\mathrm{R}}$. californicus was determined from chance in situ observations made with the ROV at numerous benthic sites between September 1988 and December 1991, by dropping squid (Loligo opalescens) with the ROV and observing the seastars' reactions to introduced food (10/18/91), and by observing individuals kept in aquaria at various times between March and December 1991. Dead 
smelt and squid were fed to $\underline{\mathrm{R}}$. californicus kept in aquaria at the Fish and Game facility at Granite Canyon and at Moss Landing Marine Labs. Dead fish and squid and live crustaceans were fed to $\underline{\mathrm{R}}$. californicus kept at the Monterey Bay Aquarium. Reaction to prey items and methods of handling prey were annotated to qualitatively describe feeding behavior.

\section{RESULTS}

Forty-eight specimens of Rathbunaster californicus were collected during seven dives at C4-C5. Ten of the seastars from C4-C5 had empty stomachs, 32 contained a moderate amount of prey, and six had large amounts of prey in their stomachs. Fifty specimens were collected during three dives at Soquel. Thirteen of the $\underline{R}$. californicus stomachs from Soquel were empty, 35 were moderately full, and two contained large amounts of prey.

At both sites, the overall diet of $\underline{R}$. californicus was highly varied (Table 6 ). $\underline{R}$. califomicus appeared to be primarily an opportunistic predator and scavenger. The presence of midwater animals such as large decapod shrimps, hyperiid amphipods, other midwater crustaceans, siphonophore parts, and a tomopterid polychaete indicates that $\underline{\mathrm{R}}$. californicus may be capable of catching highly mobile swimming prey.

At both sites, most $\underline{\mathrm{R}}$. californicus stomachs contained sediment and whole crustaceans or crustacean parts (Fig. 11). At both sites, fish parts, mollusc remains, whole crustaceans, crustacean parts, and sediment were found in similar percentages in stomachs and incidental material. Also at both sites, polychaete parts, foraminifera, and fecal pellets were found more frequently in incidental material than in stomach contents. The most abundant organism found in $\underline{\mathbf{R}}$. californicus stomachs was a caprellid amphipod. 
Table 6. Overall list of prey items of Rathbunaster californicus from Monterey Submarine Canyon. ( ${ }^{* *}=$ laboratory observations, ${ }^{*}=$ in situ observations, all others from stomach content analysis.)

\section{Vertebrates}

Herring**

Smelt**

Anchovy**

Myctophid*

Unidentified fish*

fish scales

fish vertebrae

Molluses

Squid (Loligo opalescens) ${ }^{* *}$

Gastropods

Small bivalves

Shell fragments

Crustaceans

Krill (Euphausia sp.)**,*,in stomach

Brine Shrimp (Artemia sp.)**

Sergestids*,in stomach

Whole decapods

Caprellids

Gammarid amphipods

Hyperiid amphipods

Ostracods

Isopods? (Gnathiidae)

Miscellaneous unidentified crustaceans

Sergestid antennae

Crustacean antennae

Caprellid eggs

Crustacean parts

\section{Echinoderms}

ophiuroid parts--articulating ossicles

echinoid parts (Allocentrotus fragilis)

Polychaetes

Maldanidae

Spionidae

Tomopteridae

worm tubes

setae

other worm parts

\section{Nematoda}

Unidentified

Eoraminifera

3 types

Miscellaneous

sand \& mud (sediment)

detritus

fecal pellets

red masses (crustacean parts)

sponge spicules

spines

miscellaneous hard parts

siphonophore piece?

chaetognath parts?

salp?*

gelatinous masses 

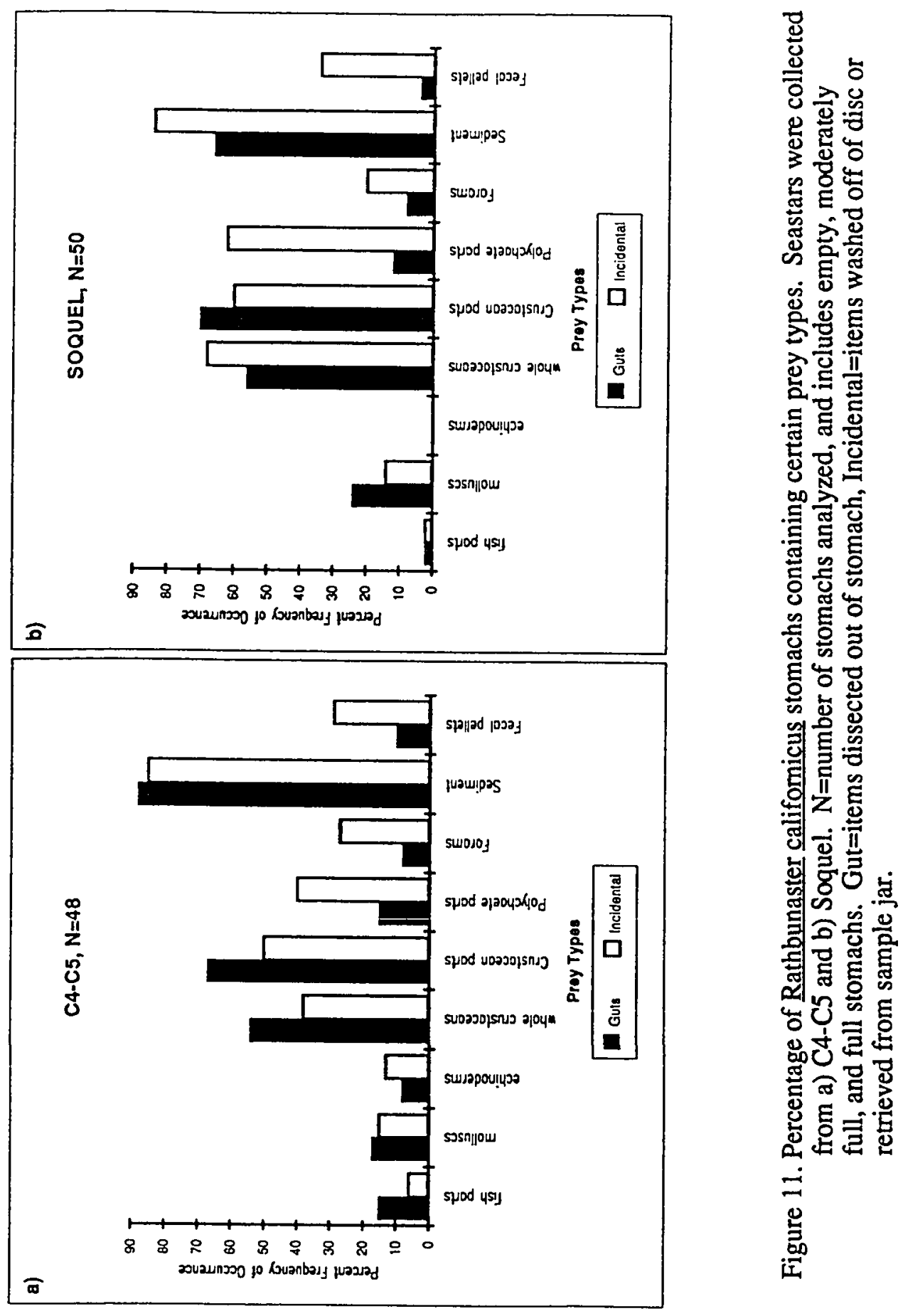
Rathbunaster californicus was observed in situ catching pelagic organisms such as euphausiids, sergestids, and in one case, a myctophid. Two $\underline{\mathrm{R}}$. californicus were found associated with the remains of a gelatinous organism, tentatively identified as a dead salp. One seastar was found associated with part of a dead fish, presumably cut into pieces by the ROV's thrusters.

At the Soquel site, two sets of dead Lolige opalescens were weighted and dropped by the ROV onto soft substrate (at $475 \mathrm{~m}$ and $450 \mathrm{~m}$ ) in an area of high seastar abundance, to observe feeding behavior of $\underline{R}$. californicus. Seastars located downcurrent from the bait moved rapidly towards it $(n=4, n=4)$, but none actually ingested the dead squid. The experiments ended abruptly when the bait was eaten by sablefish (Anoplopoma fimbria).

In the laboratory, everything offered to $\underline{R}$. californicus was eaten (Table 5). They used their pedicellariae to catch mobile prey such as brine shrimp (G. Van Dykhuizen, MBA, pers. comm.). When fed large prey items such as smelt or pieces of squid, $\underline{\mathrm{R}}$. californicus did not evert its stomach, but engulfed the whole prey item.

\section{DISCUSSION}

The number of empty stomachs and paucity of very full stomachs indicated that

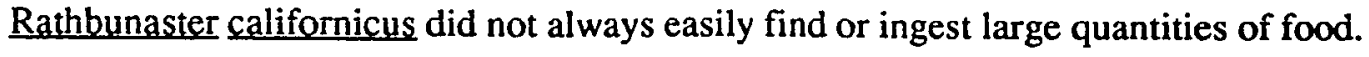
Sampling methods may have biased this interpretation, because $\underline{\mathbf{R}}$ californicus may have egested food during transit from benthos to surface. In addition, gelatinous prey or other items easily digested would not have been found or counted. However, it is possible that $\underline{\mathrm{R}}$. californicus is food limited. It may be even more likely that it does not require much food to maintain itself. Rathbunaster californicus can approach the size of Pycnopodia helianthoides in the laboratory, but is never found this large in the field. No data are available on metabolism rates of $\underline{\mathrm{R}}$. californicus, but it is plausible that the 
seastar survives on a maintenance diet that may be supplemented occasionally by nekton falls or live benthopelagic prey.

Most of the prey items found in $\underline{\mathrm{R}}$. californicus stomachs were small (under 1 $\mathrm{cm})$. The only evidence of $\underline{R}$. californicus feeding on large benthic megafauna came from several stomachs containing urchin parts; however, for several hours during recovery of the ROV, these seastars were kept in the sample drawer with a damaged urchin (Allocentrotus fragilis). Rathbunaster californicus may be restricted to eating smaller prey items, as seastars kept in the laboratory appeared to have difficulty engulfing large pieces of fish or squid. When squid were presented to $\underline{R}$. californicus in situ, the seastars also appeared to have problems with the size of the prey.

Distinguishing actual food items from items ingested incidentally during feeding is a problem encountered in many diet studies. For $\underline{R}$. califomicus, the similarity of percent frequency of occurrence of fish parts, mollusc parts, whole crustaceans, and crustacean parts found in gut contents and incidental material indicates that these items really were prey items (Fig. 11 a-b). The most abundant prey items, caprellid amphipods, were found in much greater abundance inside $\underline{\mathrm{R}}$. californicus stomachs than in incidental material. Polychaete parts, foraminifera, and fecal pellets were more frequent in incidental material than in the stomachs, and were probably ingested by chance. Sediment was abundant both in stomachs and in incidental material. Sediment was deposited into the drawer during collection of $\mathbf{R}$. californicus, and it was impossible to tell whether ingestion of sediment was normal or if it was an artifact of sampling.

Overall, this study supported the results of Fisher (1928) and Carey (1972). Rathbunaster californicus is a predator and scavenger that can catch midwater organisms with its pedicellariae, tube-feet, and arms. The reports of midwater feeding may have been biased because many crustaceans and fish are attracted to, or become confused by, ROV lights. It was impossible to tell whether such interactions would 
occur naturally. Midwater prey items were found in $\underline{\mathrm{R}}$. californicus stomachs, but these prey could have been freshly dead and scavenged from the bottom, or ingested during collection, when ROV lights were on, or during transit, when prey could have been trapped in the volume of the drawer. However, when presented with the opportunity, either in situ or in the laboratory, $\underline{\mathrm{R}}$. californicus did respond by catching mobile prey. This ability has been reported for other forcipulate asteroids (Robilliard, 1971; Chia and Amerongen, 1975; O'Brien, 1976; Dearborn, 1977; Dearborn et al., 1981), and could be a selective advantage. Robilliard (1971) hypothesized that feeding by chance encounter of pedicellariae and mobile prey item would take little expenditure of energy, represent a large net energy gain, and allow search and intake of other food sources. Information on such benthopelagic phenomena is scarce, but these findings may indicate that this is a common mode of feeding.

That $\underline{\mathrm{R}}$. californicus scavenged remains of fish and midwater gelatinous organisms was not surprising. Facultative necrophagy as a dietary supplement has been reported among Antarctic seastars, and Amaud (1970) hypothesized that this tendency would also be developed at great depths. Jangoux (1982) reported that some seastars are facultative scavengers even though none seem to this as a primary food source. Rathbunaster californicus responded quickly to food introduced in situ and in the laboratory. The seastar found associated with part of a dead fish must have responded within minutes. The fish was sliced cleanly, indicating that it had gone through the ROV thrusters, and it looked very fresh, indicating that it had occurred recently. This ability to respond to nekton falls, organic detritus, and other irregular food sources might also place $\underline{\mathrm{R}}$. californicus at an advantage.

In Monterey Bay, $\underline{\mathrm{R}}$. californicus is an opportunistic predator/scavenger. Because dietary breadth is not a consistent species property throughout geographic range (Fox and Morrow, 1981), it is possible to predict only how $\underline{\mathrm{R}}$. californicus feeds 
over its whole range, but not exactly what it eats. However, based on the opportunistic feeding strategy, it is probable that the diet of $\underline{\mathrm{R}}$. californicus in any location would reflect availability of prey.

Rathbunaster californicus is a predator, but the interactions and trophic links between species are difficult to decipher because so little is known about any of the other members of this environment. Except for Allocentrotus fragilis, none of the organisms found associated with $\underline{\mathrm{R}}$. califormicus in the habitat study were found in analysis of stomach contents or incidental items (Fig. 10 a, c, Fig. 11 a-b). The presence of Allocentrotus fragilis in the stomach contents was probably an artifact of sampling, and urchins are probably not regular prey items. The prey items commonly found during stomach content analyses were too small to be identified during the habitat study, and those in the habitat study were probably too large to be ingested by $\underline{R}$. californicus. In addition, benthopelagic prey items found during stomach content analysis were not annotated during the habitat study.

Because of many problems associated with accurately determining diet, the scope of this part of the study was necessarily narrow. With limited resources and dive time, it was not possible to quantitatively determine predator and prey distributions and dispersion or prey availability. To do so would have required extensive unbiased sampling. Whether or not selection of prey items occurred was impossible to determine. Prey items were difficult to identify. Many items were decomposed, and many of the crustaceans were missing appendages necessary for identification. However, defining methodology and creating a potential prey item list was important in describing natural history of $\underline{R}$. californicus. In deep-water, where even prey items in good condition can be difficult to identify, such pilot studies are essential. 


\section{PARASITISM OF RATHBUNASTER CALIFORNICUS IN MONTEREY BAY}

\section{INTRODUCTION}

Some members of the large population of Rathbunaster californicus inhabiting the Monterey Submarine Canyon are infected by an endoparasitic gastropod. This parasite has not been reported previously from Monterey Bay, but it resembles Asterophila japonica Randall and Heath, a species found in two other genera of seastars (Randall and Heath, 1912; Hoberg et al., 1980). The parasite found in $\underline{\mathrm{R}}$ californicus may be a new species of Asterophila, yet to be described and named.

All classes of echinoderms contain individuals infected by members of the Eulimidae, an entirely parasitic group of prosobranch gastropods (Waren, 1983). Most eulimids are ectoparasites, and some authors use this as a definitive trait (Morton, 1979; Taylor, 1975), despite the presence of endoparasitic representatives. Eulimids are usually attached permanently to their hosts, and eulimid genera often are specific to the same class or lower taxon of hosts (Waren, 1983). There is no evidence that any eulimids infect intermediate hosts. Ectoparasitic eulimids often use a long proboscis to penetrate their host's body wall to remove fluid and tissue, unlike most endoparasitic eulimids, which attach to the body wall of their hosts (Waren, 1983).

Degradation of typical prosobranch characters is apparent in the transition from ectoparasitism to endoparasitism (Grusov, 1965a). Various combinations of foot reduction, mantle organ reduction, growth of a pseudopallium, digestive tract simplification, shell and operculum loss, absence of the radula, and hypertrophy of the gonadal system are typical of eulimid parasites. Sexual dimorphism, neotenic males, and brooding of young also are common. The most extreme modifications are found in endoparasitic eulimids, making identification difficult (Grusov, 1965a). Little is known about the life cycle of eulimids, except that larvae exhibit typical molluscan 
development, passing through a trochophore and a veliger stage (Waren, 1983). Some eulimids exhibit planktotrophic larval development while others produce lecithotrophic larvae, and it appears that all eulimids have a free-living larval stage (Bouchet and Waren, 1979; Waren, 1983)

Asterophila japonica is an endoparasitic eulimid described from four specimens of Pedicellaster sp. dredged from $82 \mathrm{~m}$ to $2430 \mathrm{~m}$ in the Sea of Japan (Randall and Heath, 1912). In these specimens, Asterophila japonica was found in the coelom of one or more arms in each host, attached by connective tissue to the body wall near the ambulacral ridge. The parasite found in Pedicellaster sp. was shell-less, all organs were enveloped in the pseudopallium, and the whole organism was manifested externally as an enlarged gall in the seastar arm. All organs were reduced except for the reproductive system. Asterophila larvae were visible in the pseudopallial cavity of the adult female parasite. A subsequent study by Grusov (1965b) provided more detailed description of morphology and systematics of this organism and described the enlarged gall as the female, with tiny neotenic males attached to the surface. Asterophila japonica also has been found inside the arms of Leptasterias polaris acervata, $L$. groenlandica, and $\underline{L}$. arctica from the southeastern Chukchi Sea and northeastern Bering Sea (Hoberg et al., 1980).

Endoparasitic gastropods resembling Asterophila japonica were found inside the arms and discs of specimens of $\underline{\mathrm{R}}$. californicus collected with MBARI's ROV in the Monterey Submarine Canyon (Fig. 12). The parasite was discovered in September 1990, when veliger larvae spilled out of an incision in a $\underline{\mathbf{R}}$. californicus arm. Based on the presence of veliger larvae and the echinoderm host, the parasite was identified as a member of the Eulimidae. The adult parasite was visible externally as a swelling in the arm, and when removed from the arm for identification, it resembled $\underline{A}$. japonica, which is the only shell-less endoparasitic genus of the Eulimidae known to infect 

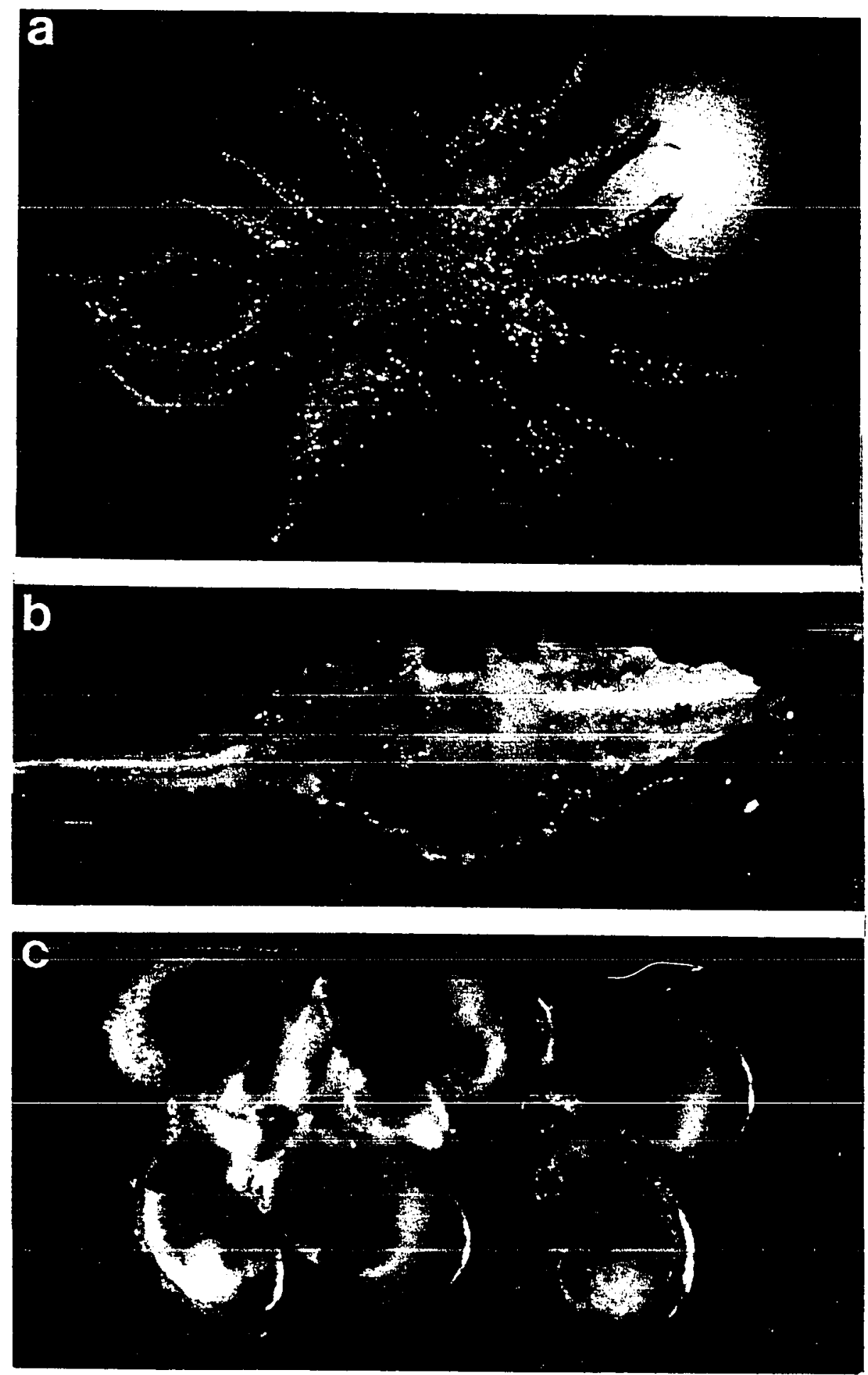

Figure 12. a) Rathbunaster californicus infected by the endoparasitic gastropod Asterophila sp. The parasites are visible externally as galls, or swellings, in the seastar's ray. b) Dissected $\underline{R}$. californicus arm, showing Asterophila sp. c) Veliger larvae from Asterophila sp. $(400-500 \mu \mathrm{m})$. 
asteroids. Characters essential for species identification within the genus Asterophila were not available, and without conclusive identification it was not certain that the species in Monterey Bay was A. japonica. It will hereafter be referred to as Asterophila sp.

Most researchers working on the Eulimidae have concentrated on taxonomy and phylogenetic relationships and ignored the ecology and population dynamics of the parasites and the effects of parasitism on host individuals or populations. Analysis of video data recorded after discovery of the parasite, as well as analysis of tapes used in the habitat use study, indicated differences in incidence of parasitism in different areas of the canyon. This apparent pattern and the dearth of information about Asterophila prompted further work.

The objectives of this part of the study were to identify the parasite found in $\mathbf{R}$. califomicus, describe parasite-host distribution patterns in Monterey Bay, and study the general biology of the host-parasite interaction, specifically looking for any effects of the parasite on the morphology of $\underline{R}$. californicus. ROV field observations, dissection of collected specimens, and laboratory experiments were combined to examine these questions.

\section{MATERIALS AND METHODS}

All observations and collections were made with the MBARI ROV and took place at sites in the Monterey Submarine Canyon (Fig. 2). Most of the visual observations and all of the specimen collections occurred at the Soquel and C4-C5 sites. The animals collected and dissected in this study were the same animals used for gut content analysis in the preceding section. Some of the visual observations of infected

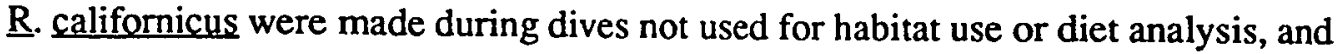
were extracted from the MBARI database. 


\section{Identification of Parasite}

To identify the parasite, specimens of Asterophila sp. from Monterey Bay Rathbunaster californicus and Alaskan Leptasterias sp. were compared. Specimens of Leptasterias sp. reportedly infected by $\underline{A}$. japonica were obtained from $\mathrm{H}$. M. Feder in Alaska (collected in the Chukchi or Bering Sea in 1980). These had been fixed in formalin and stored in isopropyl alcohol. The adult parasites were removed from their hosts and characteristics of the external morphology noted. Adults were pierced to free the larvae, and larvae were observed under a compound microscope at 10X magnification. Different stages of larval development were recorded with a $35 \mathrm{~mm}$ camera mounted on the microscope. Samples of the larvae also were prepared for viewing with a scanning electron microscope (SEM). Samples were stained with osmium tetroxide, run through a $10 \%$ stepwise dehydration process using pure ethanol, critical point dried, mounted, sputter coated with gold, and examined with the SEM. Samples of the adult parasite from $\underline{\mathbf{R}}$. californicus were also sent to a eulimid expert, Anders Waren, for identification.

\section{Distribution of Parasite in Monterey Bay}

Because large Asterophila sp. were visible externally as swellings in the arms of

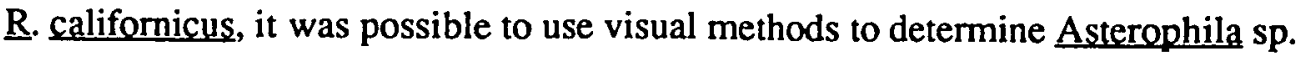
distribution of in Monterey Bay. The north, east, south, and west extremes reached by the ROV on all dives between April 1989 and November 1991 where parasitized $\underline{\mathbf{R}}$. californicus were seen were plotted to illustrate overall incidence of parasitism in Monterey Bay.

MBARI scientists most frequently visit the Soquel and C4-C5 dive sites 
(Fig. 2). Visual surveys, or "spot checks," for parasitized $\underline{\text { R. californicus were }}$ conducted at these two sites at similar depths (between 250-650 m) between December 1990 and November 1991. Spot checks consisted of visually inspecting the first 25 seastars encountered by the ROV after the initiation of a survey. Close-up video sequences of each seastar were recorded, and site, depth, number of arms, and presence or absence of parasites were noted for each specimen (seastars were recorded only as infected or uninfected; number of infections/seastar was not analyzed). Percent of infected $\underline{\mathrm{R}}$. californicus was calculated for each dive. Percentages were compared between sites with histograms and the Mann-Whitney U Test.

Large parasites were easily detected by external visual inspection, but it was hypothesized that the actual number of infected seastars might be underestimated because small parasites might not give an external surface manifestation. To check the accuracy of visual surveys, percentage of infected $\underline{R}$. californicus determined by spot checks and by dissection were compared. Specimens of $\underline{\mathbf{R}}$. californicus from C4-C5 $(\mathrm{N}=46)$ and Soquel $(\mathrm{N}=50)$, collected for stomach content analysis, were dissected to check for presence or absence of Asterophila sp. Presence or absence of Asterophila sp. in these specimens was determined visually by analysis of the video data recorded during collection. Several of the seastars recorded on video never were recovered, so that the number of seastars inspected visually was sometimes greater than the number dissected. Percent infection determined by the two methods was compared with a histogram.

\section{Biology of Host-Parasite Interaction}

A subset of the 96 specimens ( 26 from C4-C5, 24 from Soquel) was used to examine the host-parasite interaction. Effect of parasitism on $\underline{R}$. californicus reproductive tissue was investigated by comparing a gonad index between arms of an 
individual seastar and among seastars. Rathbunaster californicus has two gonads per arm that open to the outside near the base of the arm. Dry weight of gonad (mg)/length of arm (mm) was used as an index. Length of arms was measured to the nearest millimeter with dial-type calipers. Gonads were dissected from seastar arms, dried at $60^{\circ} \mathrm{F}$, and weighed to the nearest milligram on a Cahn C-31 microbalance. For nonparasitized seastars, arm length was averaged, and gonads were dissected from the longest, shortest, and four average length arms. For infected seastars, gonads were dissected from all parasitized arms and equivalent length non-parasitized arms, if present. Arm length was plotted against gonad weight for specimens from each site to examine potential localized effects on single arms. Correlation analysis was not performed because the samples were non-random and were not independent. To calculate an index for each seastar to compare whole animals, the gonad index for all non-parasitized arms sampled was averaged, as was the gonad index for all parasitized arms. Means and standard deviations were plotted in a histogram.

Several parameters were recorded to examine potential trends in host-parasite interactions. The number of Asterophila sp. per seastar, size of the parasite, wet weight of the parasite relative to wet weight of the host, wet weight of $\underline{R}$. californicus, and average number of arms per seastar were recorded for some or all of the $\underline{R}$. californicus dissected. Rathbunaster californicus arms were examined for openings to the outside, and Asterophila veliger larvae were examined for morphological clues for planktotrophic or lecithotrophic development. Several parasitized and non-parasitized R. californicus were maintained for observation between March and May 1991 at the Fish and Game facility at Granite Canyon on the Big Sur Coast, California, and at the Monterey Bay Aquarium. They were examined periodically for signs of dispersal of Asterophila larvae or new infection by Asterophila sp. 
RESULTS

Identification of Parasite

Blastula, trochophore, and veliger stages of Asterophila sp. were found in samples of Leptasterias sp. and Rathbunaster californicus . A two-celled and a fourcelled stage were also observed in samples from $\underline{\mathbf{R}}$. californicus. The trochophore stage was more top-shaped than a typical trochophore, and an apical tuft was not visible in samples from either host. The veligers from both seastars ranged from $400-500 \mu \mathrm{m}$, had an operculum, periostracum, either a two- or four-lobed velum, and dextrally coiled shells. Compound microscope and SEM analysis indicated similar external morphology of veliger larvae from the Monterey Bay $\underline{\mathrm{R}}$. californicus parasites and the Alaskan Leptasterias sp. parasites (Fig. 13). Anders Waren (pers. comm.) indicated that he thought the parasite from $\underline{R}$. californicus was a new species of Asterophila because there was more remaining of the foot and tentacles and the veliger larvae were larger than in A. japonica (pers. comm.).

Analysis of adult female parasites in $\mathbf{R}$. californicus indicated that all stages of parasite larval development could be found in one seastar, but all larvae within a single adult Asterophila were at the same developmental stage. Different adult parasites with different developmental stages of larvae were present in the same arm of the host. There did not appear to be a strong correlation between the size of the cyst and the developmental stage of the larvae; veligers and less developed larvae could be found in both large and small adult parasites. This correlation was not tested statistically.

\section{Distribution of Parasite in Monterey Bay}

Infected seastars have been observed in many areas of the canyon over the past three years (Fig. 14a), indicating that while percentages of infected individuals might 

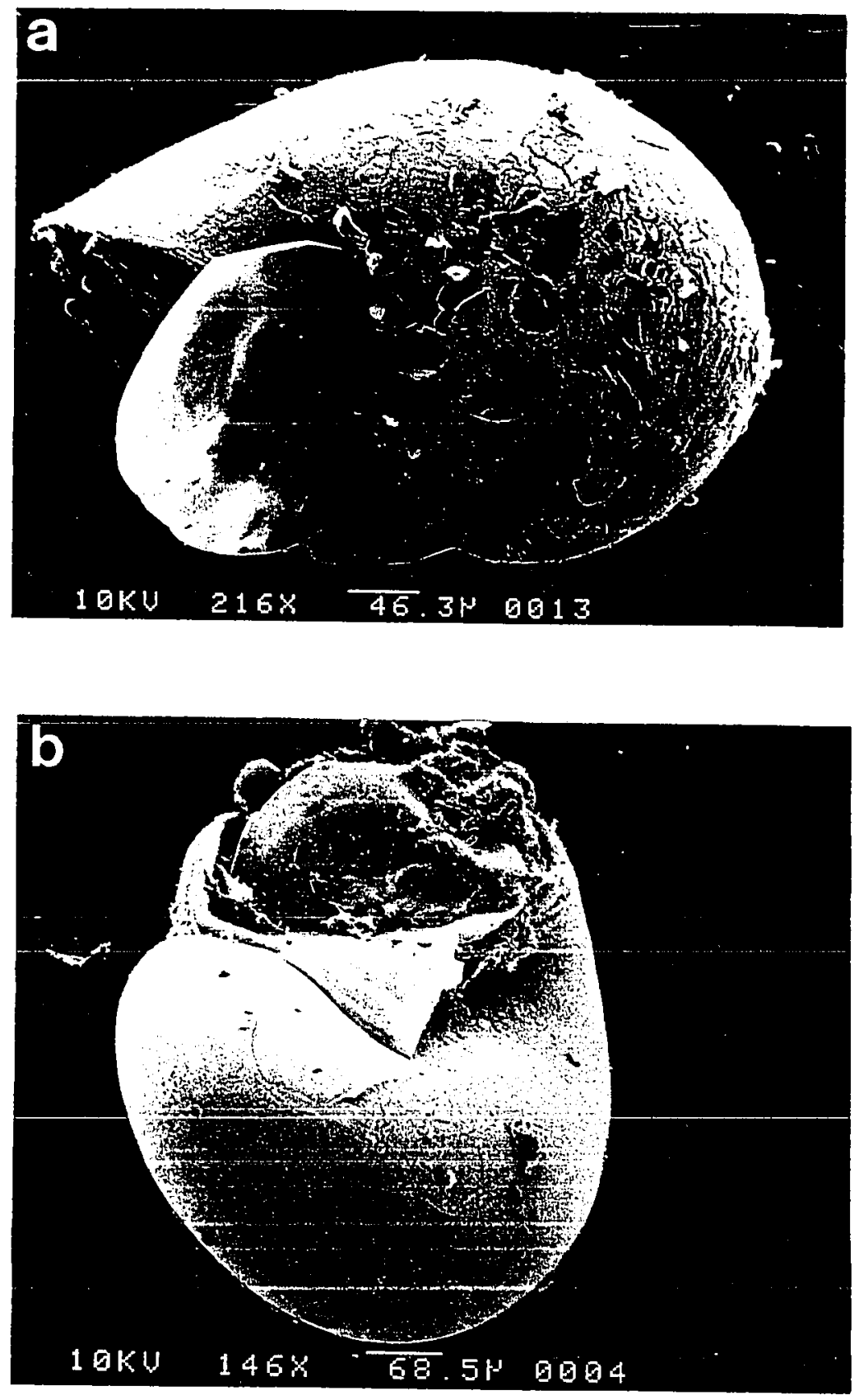

Figure 13. Scanning Electron Micrographs of Asterophila sp. veliger larvae from a) Monterey Bay Rathbunaster californicus and b) Alaskan Leptasterias sp. 
vary from site to site, the parasite is present throughout the $\underline{\mathrm{R}}$. californicus population of Monterey Bay.

Eight spot checks were conducted at Soquel, between $293 \mathrm{~m}$ and $646 \mathrm{~m}$.

Twelve surveys were conducted at C4-C5 between $271 \mathrm{~m}$ and $523 \mathrm{~m}$. Asterophila sp. was found in seastars in all eight surveys at Soquel and in six of twelve surveys at C4C5 (Fig. 14b). Percentage of infected $\underline{\mathrm{R}}$. californicus was significantly greater at Soquel than at C4-C5 (Mann-Whitney U Test, p<0.01, Fig. 15). Mean percentage of infection was 59\% at Soquel and $8 \%$ at C4-C5. The six sites at C4-C5 where infected seastars were not seen were clustered (Fig. 14b), and deletion of these clustered surveys from analysis changed the mean percent infection at C4-C5 from $8 \%$ to $16 \%$. Percentage of infected seastars was still significantly greater at Soquel than at C4-C5 (Mann-Whitney $\mathrm{U}$ Test, $\mathrm{p}<0.01$ ).

No parasitized individuals were found during dissection of 46 C4-C5 specimens, even though an average of $8 \%$ were infected based on visual checks. Dissection of 50 Soquel specimens indicated that percentage of infected $\underline{\mathbf{R}}$. californicus determined from visual surveys was lower than from dissection $(40 \%$ vs. $100 \%, 45 \%$ vs. $90 \%, 61 \%$ vs. 97\% for three sampling periods, Fig. 16). At Soquel, the number of infected seastars may be well over the $59 \%$ average determined from spot checks.

\section{Biology of Host-Parasite Interaction}

None of the 46 C4-C5 $\underline{\mathrm{R}}$. californicus dissected contained Asterophila sp, and the 26 of these for which a gonad index was calculated were used as a control when looking for effects of parasitism on reproductive tissue of the host. There was so much variation in the gonad index between arms of one individual (Fig. 17) and among individuals from one sampling period (Fig. 18) that no pattern could be detected. Large arms with small gonads and small arms with large gonads were found. This indicated 

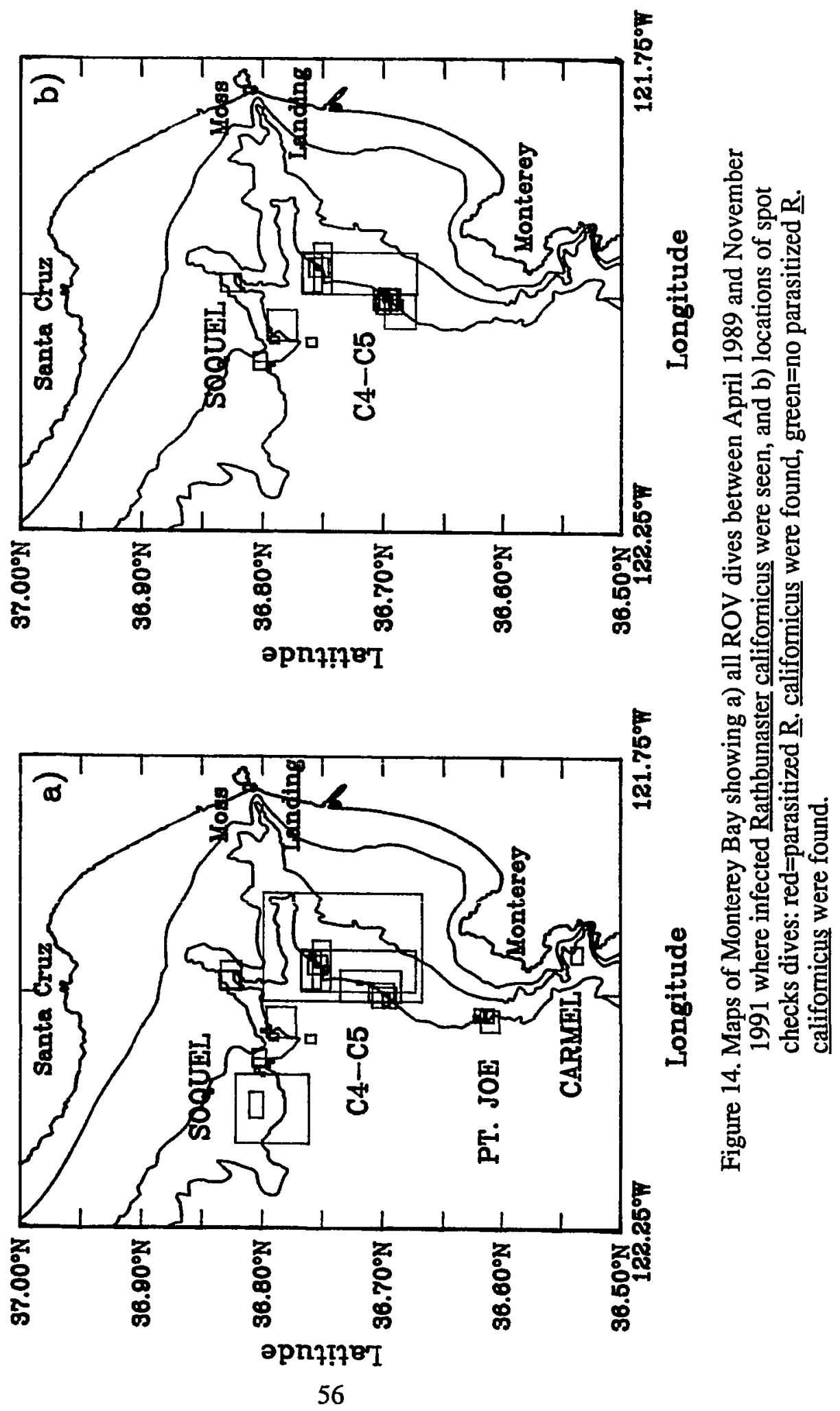
SOQUEL
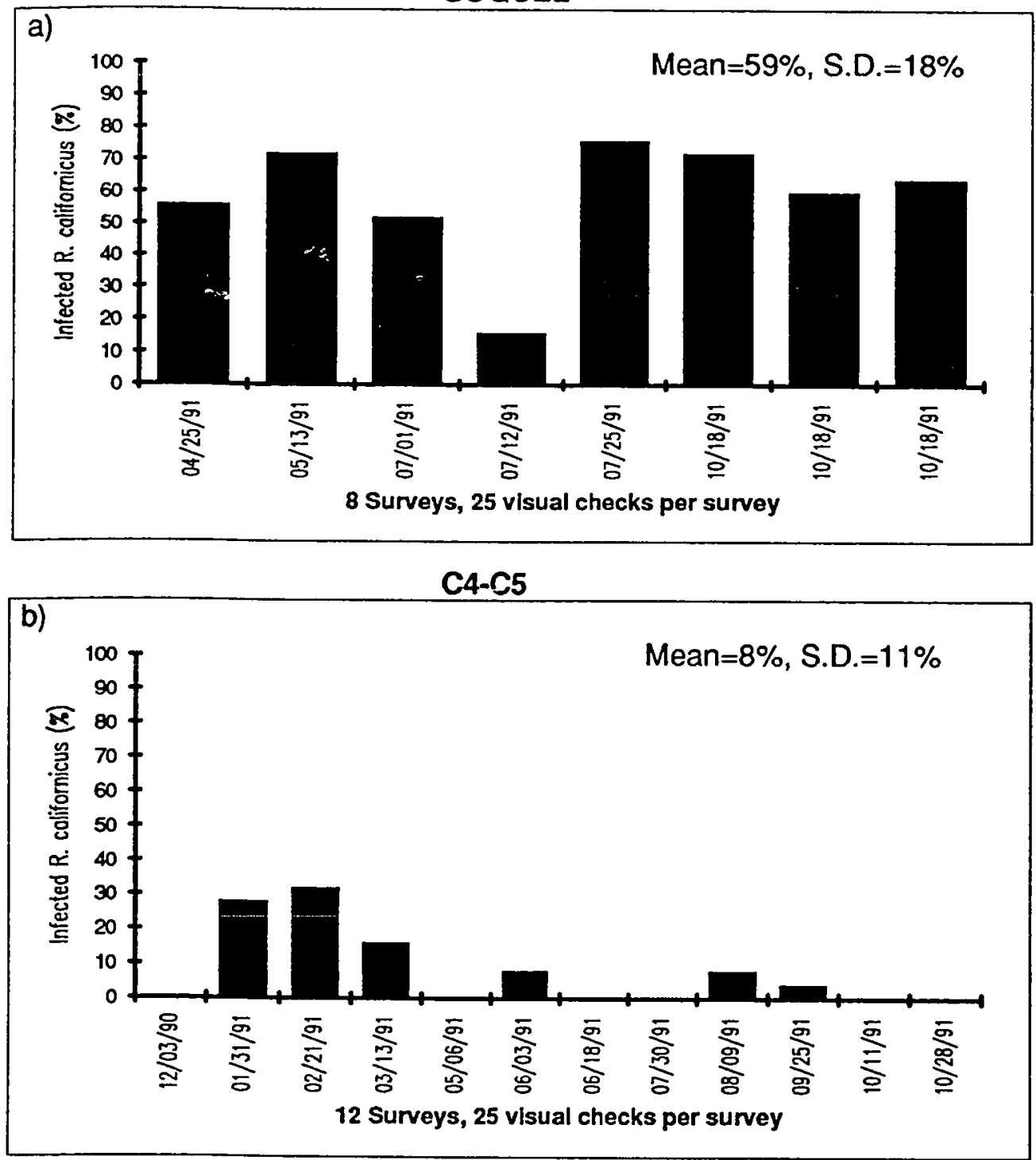

Figure 15. Percent of parasitized Rathbunaster californicus found during spot checks (visual surveys) at a) Soquel and b) C4-C5. 


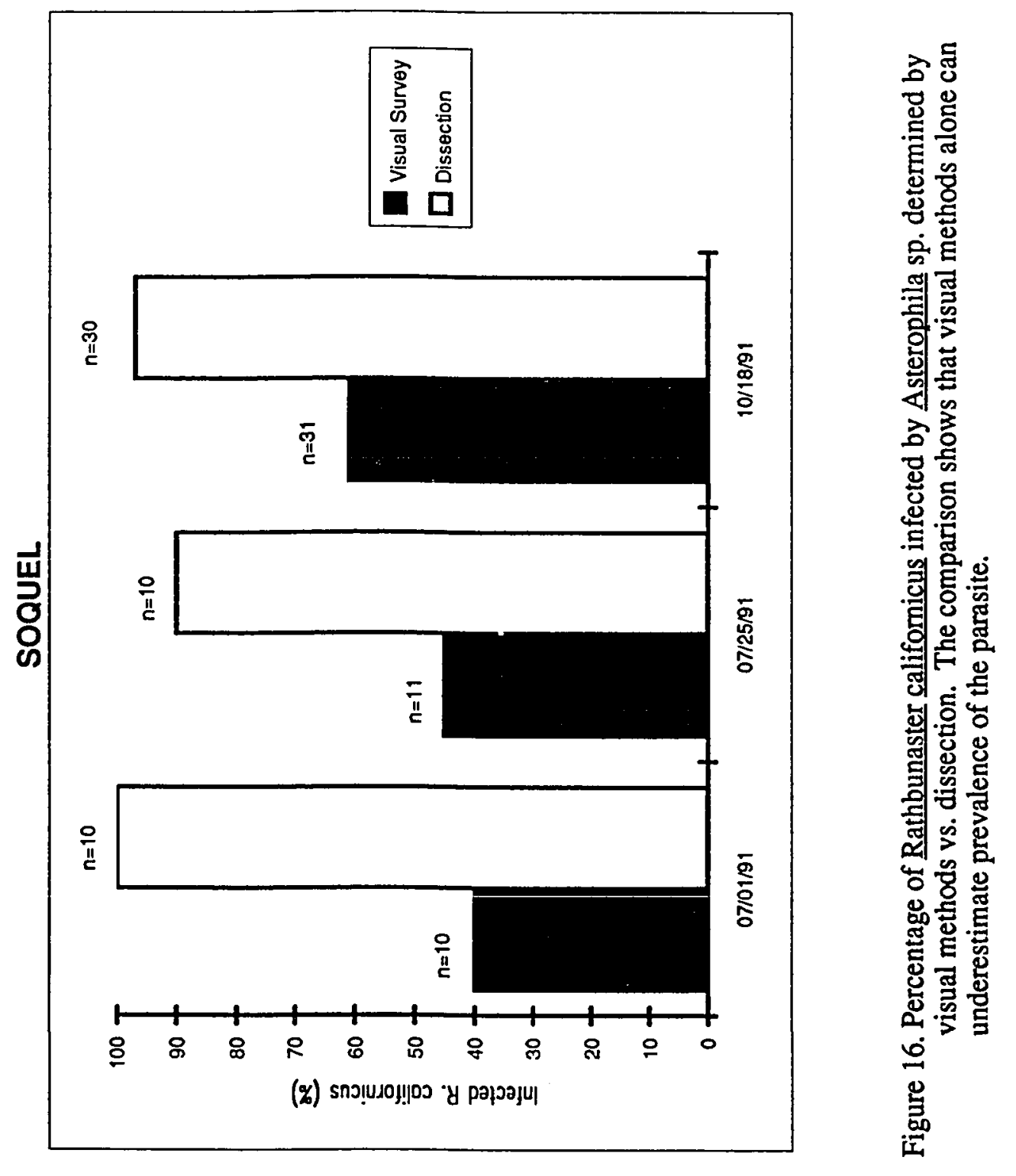



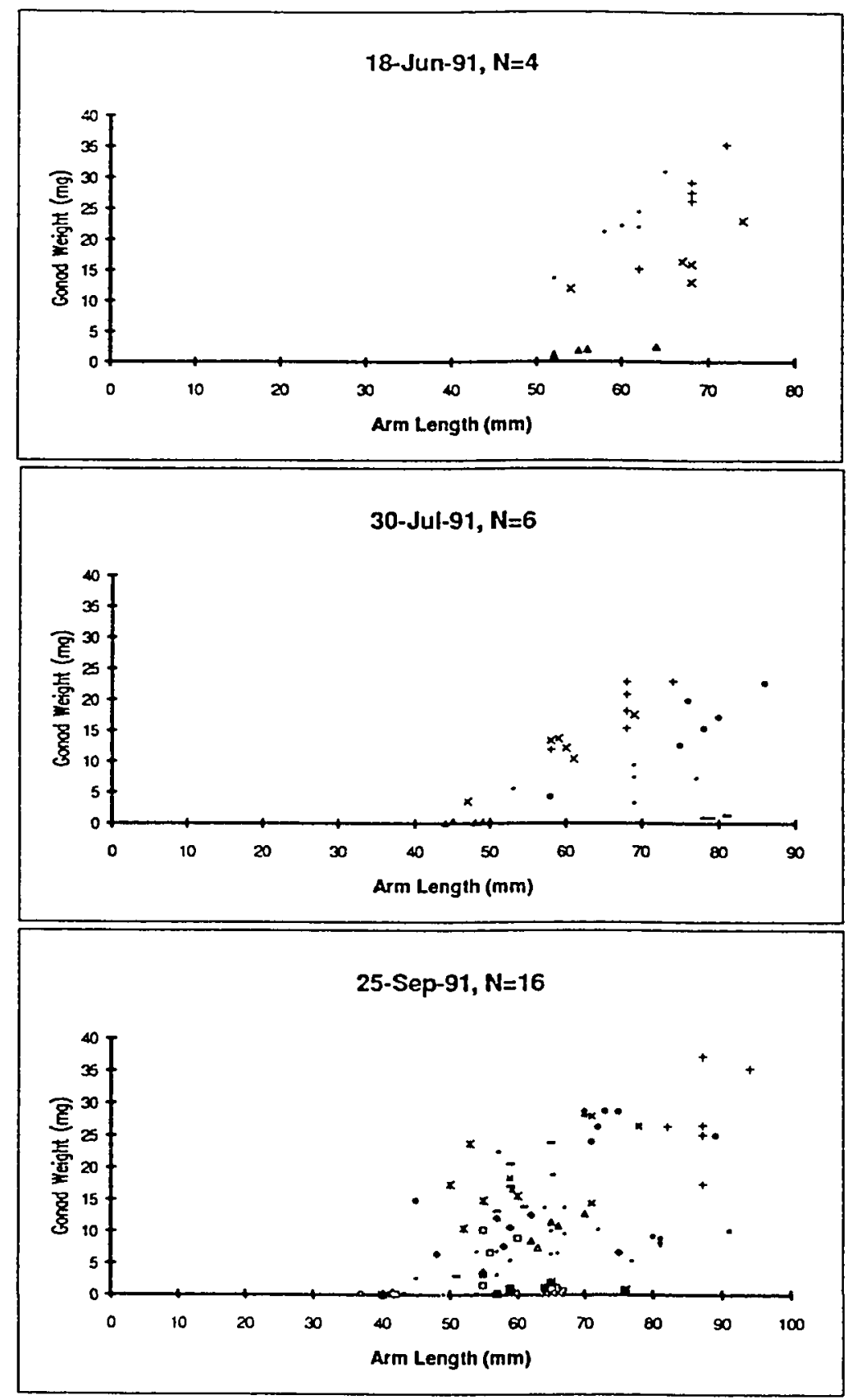

Figure 17. Arm length (mm) vs. gonad dry weight (mg) for dissected Rathbunaster californicus from $\mathrm{C} 4-\mathrm{C} 5$. $\mathrm{N}=$ number of seastars dissected. Each symbol type represents a different individual seastar; each data point represents a single arm. 


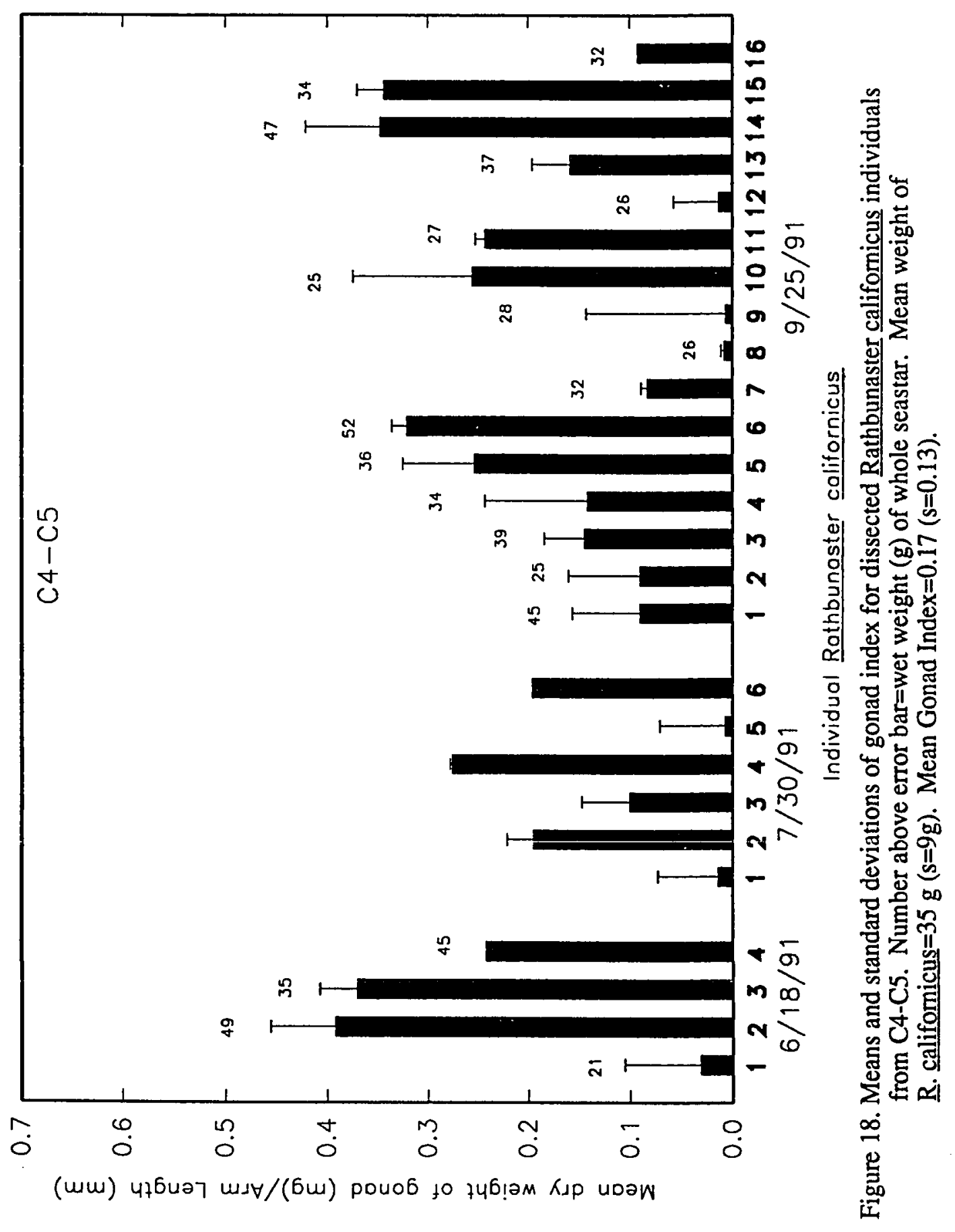


that $\underline{R}$. californicus was not a synchronous spawner and that even the arms of one individual were not synchronized. No pattern was visible when the same type of data was plotted for parasitized and non-parasitized arms for 24 Soquel specimens (Fig. 19, Fig. 20). When the gonad index for all seastars from each site were averaged, the mean value was higher at $\mathrm{C4-C5}(\bar{x}=0.17, s=0.13)$ than at Soquel $(\bar{x}=0.05, s=0.09)$. The mean gonad indices for non-parasitized arms ( $\bar{x}=0.06, s=0.10)$ and parasitized arms $(\bar{x}=0.05, s=0.08)$ from Soquel specimens were similar. No obvious relationship between developmental stage of Asterophila sp. and $\underline{\mathbf{R}}$. californicus reproductive tissue was detected.

Of the 24 (of 50) $\underline{\mathrm{R}}$. californicus from Soquel for which a gonad index was calculated, one was non-parasitized, two contained one parasite, and the remaining twenty-one contained two to twenty-four individual Asterophila sp. ( $\bar{x}=11, \mathrm{~s}=7.5)$. Never were all arms of an individual $\underline{\mathrm{R}}$. californicus parasitized, but individual arms held up to six parasites. No additive effect of parasitism on reproductive tissue of the host was detected; only one of four arms containing six parasites, and one of three containing five parasites, lacked seastar gonadal tissue. Asterophila sp. specimens ranged from 1.0 to $19.5 \mathrm{~mm}$ long ( $\bar{x}=7.2, s=4.3, N=214$ ). Over $75 \%$ of seastar arms containing parasites greater than $10 \mathrm{~mm}$ also contained seastar reproductive tissue. Weight of Asterophila sp. relative to $\underline{\mathrm{R}}$. californicus weight was calculated for six seastars. Four of six seastars contained individual parasites that were greater than one percent of their total body weight. When the weights of all parasites from an individual seastar were added together, the cumulative weights ranged from $1.2 \%$ to $13.8 \%$ of the host's body weight. Finally, adult female Asterophila sp. contained large numbers of eggs and larvae. Number of larvae from four adult females were counted, and ranged from 438 to 593 larvae. 


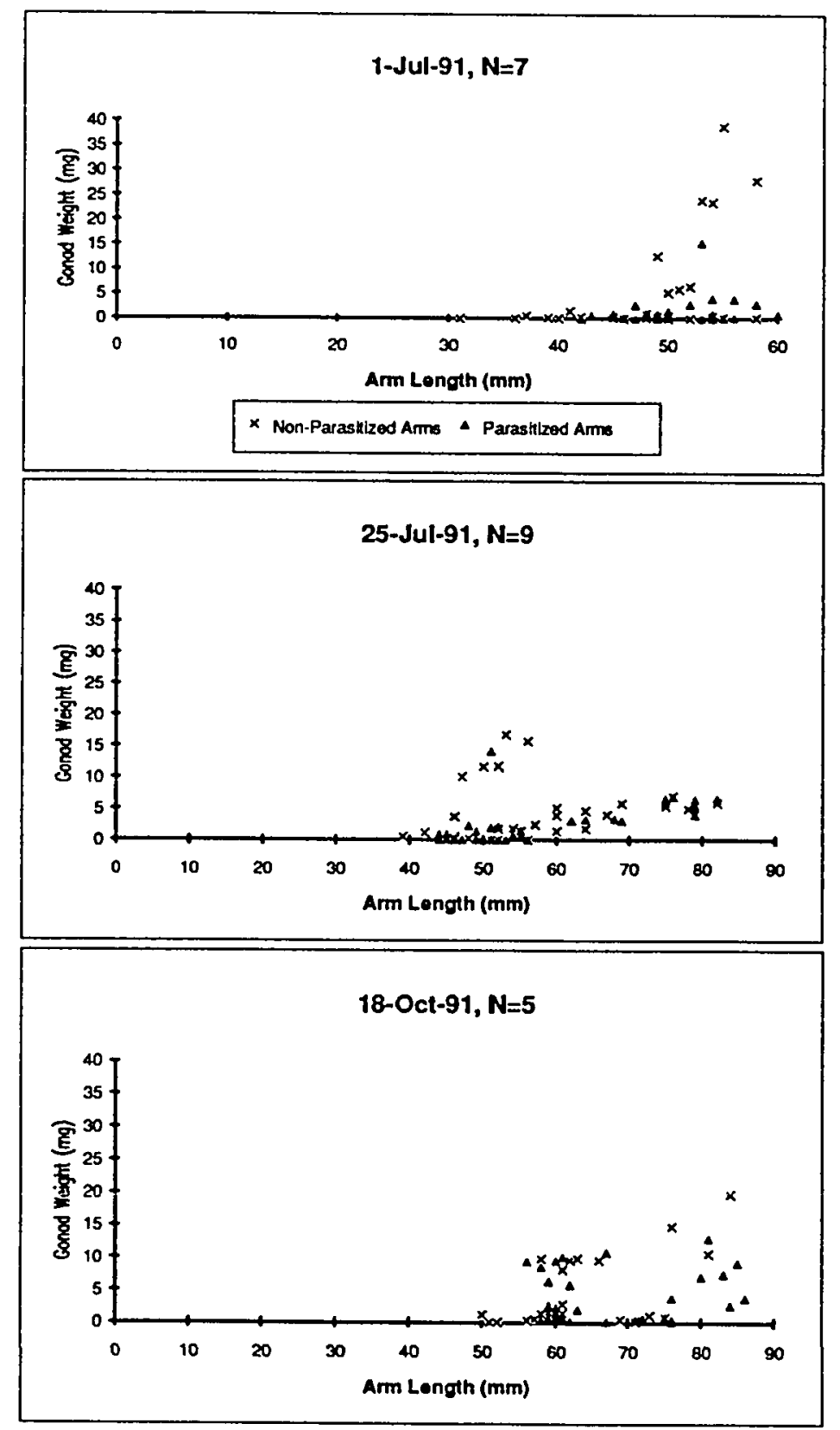

Figure 19. Arm length (mm) vs. gonad dry weight (mg) for dissected Rathbunaster californicus from Soquel. $\mathrm{N}=$ number of seastars dissected. Each data point represents a single arm. 


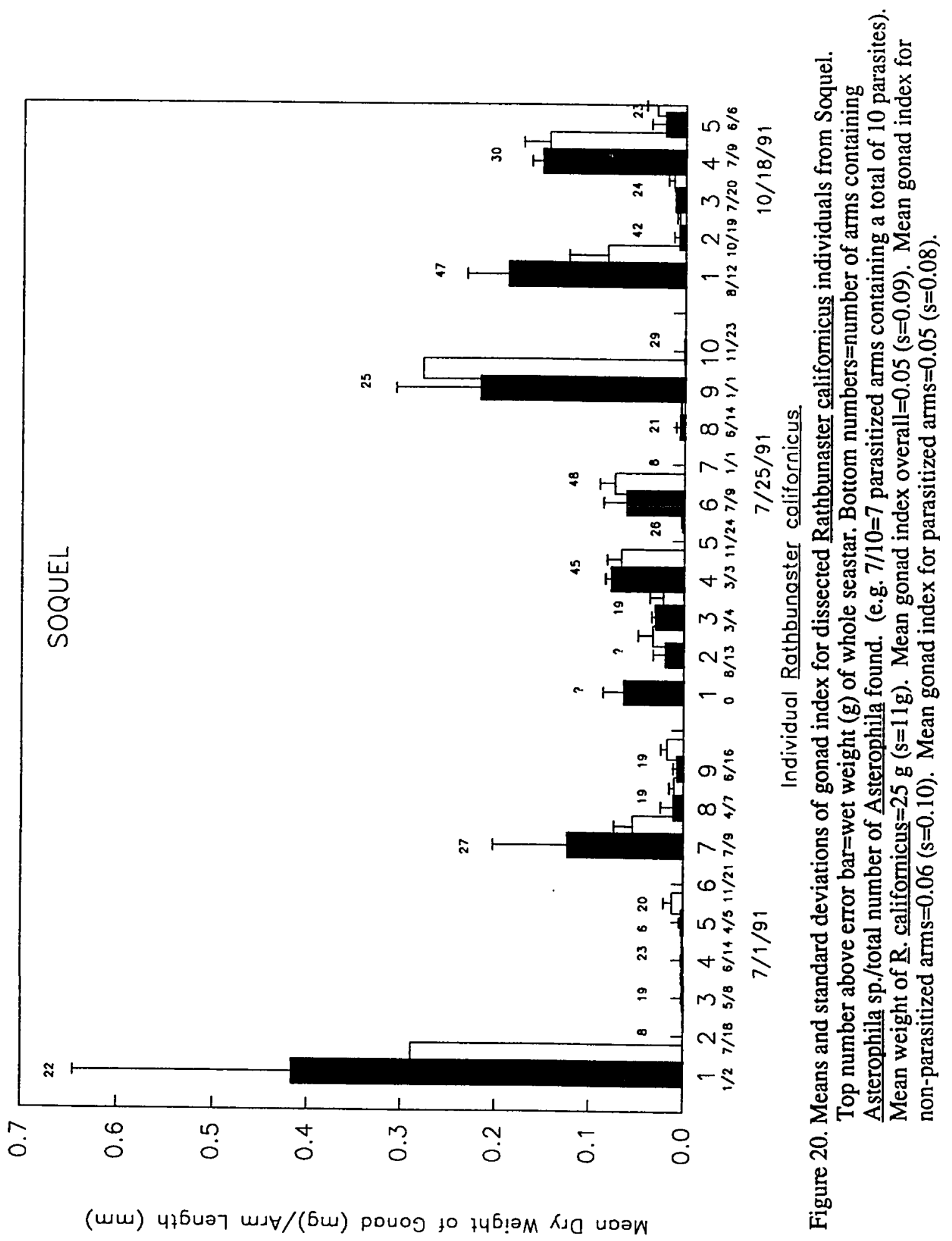


The average weight of $\underline{R}$. californicus was $30 \mathrm{~g}(\mathrm{~N}=42$, range 6-52 g). At $\mathrm{C} 4-\mathrm{C} 5$ the mean weight was $35 \mathrm{~g}(\mathrm{~N}=20$, range $21-52 \mathrm{~g})$ and at Soquel it was $25 \mathrm{~g}(\mathrm{~N}=22$, range 6-48 g). The three smallest seastars from Soquel $(8 \mathrm{~g}, 8 \mathrm{~g}, 6 \mathrm{~g})$ were all parasitized. When these were deleted, the average weight increased to $28 \mathrm{~g}$. The average number of arms per $\underline{\mathrm{R}}$. califormicus for all specimens measured was 17 [17 at C4-C5 ( $N=26$, range 16-21), and 16 at Soquel ( $N=24$, range 13-19)]. When number of arms from spot checks was included, the average number of arms for C4-C5 $\underline{\mathrm{R}}$. californicus was $16(\mathrm{~N}=300$, range $7-22)$ and 15 for Soquel $(\mathrm{N}=201$, range $10-21)$. There was no obvious relationship between weight and number of arms; even the smallest $\underline{R}$. californicus usually had more than twelve arms.

A small depression was found inside the seastar arm at the site of Asterophila sp. attachment. It remains unclear whether this serves as a means of communication to the external environment, but the depression was not visible from the outside. What appeared to be dwarf males of Asterophila sp. were found in the vicinity of several adult females.

The veliger shell of Asterophila sp. was thin and tear-drop shaped with barely one whorl. This could indicate a brief free-living stage before settling and infecting a new host, but it remains unclear whether these are planktotrophic or lecithotrophic larvae. No information about dispersal of Asterophila larvae or infection of new hosts was gained from observations of $\underline{\mathrm{R}}$. californicus kept in captivity.

\section{DISCUSSION}

The presence of Asterophila in Monterey Bay extends the geographic range of this genus around the coastal North Pacific. The parasite found in Rathbunaster californicus is probably a new species of Asterophila, but more work is needed to confirm this identification and to describe the new species. Waren cautiously used size 
of the foot, tentacles, and veliger larvae as the criteria for asserting that this parasite may be a new species of Asterophila, but he was provided with a small sample size. It is possible that average size of a larger sample of Monterey specimens would fall within the size range of $\underline{A}$. japonica. Waren does indicate that the same eulimid species can sometimes be found in hosts within the same lower taxon (Waren, 1983), and Pedicellaster spp. and Leptasterias spp., in which Asterophila sp. has been reportedly found, and $\underline{\mathrm{R}}$. californicus are all Asteriids.

However, it seems probable that there are several species of Asterophila. While the mode of larval development is not known, hosts of Asterophila are spread out over a large geographical range, and it seems improbable that $400-500 \mu \mathrm{m}$ veligers could disperse over this distance, and as adults remain capable of interbreeding and producing viable offspring. To determine if more than one parasite species existed, Asterophila veliger larvae from different asteroid host species from different geographical locations were compared, but these methods were inconclusive because larvae from both host species were highly variable. The veliger larvae from both host species superficially appeared similar. It is possible that the parasite from Leptasterias sp., identified by Hoberg et al. (1980) as $\underline{A}$. japonica, is the same species of parasite found recently in $\underline{R}$. californicus, and this eulimid is a new species of Asterophila. It is also possible that there are three different species of Asterophila. The lack of prominent and unique morphological features to use for identification indicates that molecular techniques might be a more appropriate method to identify species of Asterophila.

Percent of infected $\underline{\mathrm{R}}$. californicus was higher at Soquel than at C4-C5. This is not surprising because many parasites have aggregated distributional patterns within their host populations (Crofton, 1971). Crofton (1971) also stated that in some cases, infection increases the chance of further infection, which may explain why most infected seastars contained more than one parasite. Incidence and intensity of 
parasitism may be dependent on climatic and ecological factors that influence the probability of contact between parasite and host. Topographical features and currents in the canyon may affect dispersal and recruitment of Asterophila sp., causing spatial patchiness within different areas in the canyon and patches of hosts within one site. Asterophila sp. may be well adapted to the topographical features and currents at Soquel, explaining why percent of infected $\underline{R}$. californicus was higher at Soquel than at C4-C5. Relative to C4-C5, the Soquel site is located in a dead-end canyon with minimal currents (pers. obs.), and this type of environment may be optimal for transmission of Asterophila sp. larvae and for Asterophila sp. survival. An alternative hypothesis is that Asterophila sp. was only recently introduced into a localized area and has not had enough time to disperse and recruit heavily to other parts of the bay. This hypothesis may be supported by the graded distribution of infected $\underline{\mathbf{R}}$. californicus (Fig. 14b). Spot check data show that the number of infected $\underline{R}$. califomicus is very high at the Soquel site, intermediate to low at the upper C4-C5 site, and completely absent in the lower $\mathrm{C} 4-\mathrm{C} 5$ site. In addition, none of the dissected seastars from C4-C5 contained Asterophila, and all were collected from the lower C4-C5 site. No vertical gradient of infection was apparent. At Soquel, infected seastars were found during spot checks between 293 and $646 \mathrm{~m}$. At C4-C5, infected seastars were found during spot checks between 350 to $523 \mathrm{~m}$. The six spot checks where no infected seastars were found occurred between 271 and $647 \mathrm{~m}$.

The discrepancy between percent infection determined by visual analysis and by dissection indicates bias in the sampling scheme. Sample sizes for dissection also may have been too low; known parasitized $\underline{\mathrm{R}}$. californicus were seen in six of twelve spot checks at C4-C5, one of which took place at the lower C4-C5 site, but no Asterophila sp. were found in the 46 seastars dissected. Twenty-five seastars per visual survey was an arbitrary number based on availability of dive time and fatigue of scientists and ROV 
pilots. Larger sample sizes for visual surveys and dissections would increase confidence in these data. In addition, spot checks could only occur in areas where the ROV pilots could comfortably fly the vehicle. If this happened to be only in areas where non-parasitized $\underline{\mathrm{R}}$. californicus lived, then these spot checks would not reflect accurately the incidence within the whole seastar population. This could be a very real problem if current vector patterns and topography determine where dispersed larvae settle. Finally, single and multiple infections per seastar were counted equally in these analyses, so no infection "rates" were calculated. However, because most infected $\mathbf{R}$. californicus contained more than one parasite, the actual infection rate (\# infections/\# seastars X 100) was probably many hundreds of times greater at Soquel than at C4-C5. Unequal numbers of dives at each site and unequal numbers of spot checks for infected $\underline{\mathrm{R}}$. californicus were other sampling biases. More sampling over an increased temporal scale is needed to clarify patterns of distribution and abundance of infected $\underline{R}$. californicus. Despite these methodological problems, it seems that there is a dramatic difference in numbers of parasitized $\underline{R}$. californicus between these two sites, and the difference becomes even greater if multiple infections per seastar are considered.

Although there are a few examples of eulimid parasites causing distortion of tissue, loss of gonadal tissue, or sterility in the host (reviewed in Waren, 1983), not much is known about the effects of eulimid parasites on their hosts. Mechanical problems, cell and tissue damage, and changes in tissue type, chemical composition, growth rates, and behavior are all possible effects of parasites on hosts (Vevers, 1951; Rohde, 1982). Rohde (1982) suggests that parasitism, along with environmental stresses, can have an effect on both the physiology (weight and reproduction) of the host and on its population characteristics.

In this study, effects of Asterophila sp. on reproductive tissue and weight of $\underline{\mathbf{R}}$. californicus were examined, and no obvious effect was detected. The classic gonad 
index for echinoderms (wet weight of gonad/wue weight of whole animal) was not used because the seastars were stored in alcohol; when weighing, different rates of evaporation for different sized gonads would make this an inaccurate measure. In addition, this type of index would not allow investigation of localized effects of parasitism on a single arm. Dry weight of gonad/length of arm was used as the index, but there was so much natural variation in length of arms and weight of gonads between the arms of a seastar and between seastars that no obvious pattern was found. The gonad index and mean weight was lower for $\underline{\mathrm{R}}$. californicus from Soquel, where $96 \%$ of 50 seastars were parasitized, than for $\underline{\mathrm{R}}$. californicus from C4-C5. Mean gonad indices for non-parasitized arms and parasitized arms for specimens from Soquel were low, but were very similar to each other. The lower values could be caused by parasitism, but could also be because smaller, lighter, younger seastars were collected by chance from Soquel. Overall, sample sizes were low and it was not possible to determine cause and effect. The techniques used may not have been sensitive enough to detect effects of parasitism. Sample sizes were small, and no information about periodicity or annual cycles of gonad weight for $\underline{\mathrm{R}}$. californicus were available to compare with values obtained in this study.

It is also possible that Asterophila sp. does not affect reproductive tissue or weight of $\underline{\mathbf{R}}$. californicus, but affects some other aspect of its host's biology. The large numbers of Asterophila sp. per $\underline{\mathrm{R}}$. californicus, deformation of host tissue, and large weight of parasite relative to host imply that there must be some deleterious effect. It is common to think of parasitism as purely deleterious, but intermediate rather than high pathogenicity would be a better approach for the parasite. The parasite might suppress host or host population growth, but it would not necessarily endanger the population on which it depends. 
Finally, very little was learned about the life cycle of Asterophila sp. All were attached to $\underline{\mathrm{R}}$. californicus beside the ambulacral ridge, and sat next to a small depression in the tissue of the host. This may be what Hoberg et al. (1980) referred to as a brown-red ring found inside the arm of Leptasterias sp. that surrounded an opening to the outside. What appeared to be dwarf males were found attached to several of the larger females, and separate sexes with extreme dimorphism appear to be the norm for the species (Grusov, 1965b). Hoberg et al. (1980) described release of Asterophila sp. larvae by rupture of the seastar's arm, but this was never detected in $\underline{R}$. californicus. Other possibilities for release of larvae include autotomy of the seastar's arm and infection of the same host as the adult.

Asterophila sp. appears to use most of its resources for reproduction. Its reproductive organs remain complex while all others have degenerated, and it produces large numbers of larvae. However, no information about generation time, age at reproduction, or fecundity is available for Asterophila sp. or $\underline{\mathbf{R}}$. californicus. There is also no information available on the resources required of $\underline{R}$. californicus by Asterophila. The host provides shelter and probably food, but this study indicated that the reproductive tissue of $\underline{\mathrm{R}}$. californicus probably was not being affected by parasitism. It is conceivable that Asterophila uses $\underline{\mathrm{R}}$. californicus coelomic fluid or pyloric caeca as a food source instead. Such requirements, however, probably can not account for the observed difference in parasite distribution, unless there is an inherent difference in the host subpopulations at each site. These types of information are necessary to assess the impact of parasitism on its host population (Kennedy, 1976).

Competition, predation, and environmental factors are all important in regulating population dynamics. The effect of parasitism as a regulating force has not been as well documented, but can impact life history dynamics of a host population (Kormondy, 1984; Krebs, 1972). Parasites are common in marine and terrestrial 
habitats and require further investigation to determine their role in the ecology of their host populations. The abundance of $\underline{R}$. californicus in moderately deep waters of Monterey Submarine Canyon implies that it is an important member of the canyon ecosystem within its depth range. Presence of Asterophila sp. could influence life history parameters of subpopulations within the bay.

Data from this study provide a preliminary base for further investigations. Larval settlement traps have already been placed in many areas of the Monterey Submarine Canyon by MBARI scientists, and searching these for Asterophila larvae may help in understanding the dispersal process. Information about age at reproduction, generation time, and fecundity of both host and parasite are needed to assess the effects of parasitism on the host population. Chemical or molecular techniques might be useful in identifying effects of Asterophila sp. on $\underline{\mathrm{R}}$. californicus individuals. 


\section{SUMMARY}

The importance of natural history is often underestimated. Without understanding the biology of the organisms involved in community dynamics, wrong interpretations can be made (e.g. Dayton (1973) gave an example of acceptance of a superficially plausible model due to inadequate appreciation of natural history). This research was designed to gain information about the natural history of Rathbunaster californicus, one of the most abundant and conspicuous megafaunal animals in some areas of the Monterey Submarine Canyon.

Systematic review of video data collected by ROV revealed that $\underline{\mathrm{R}}$. californicus habitat use varied between sites, and in some cases, between depth intervals within a site. In general, at Soquel and Carmel, $\underline{R}$. californicus was found more frequently in areas dominated by hard substrate than in open, sediment slope environments.

Rathbunaster californicus was distributed in the same proportion as substrate types at Pt. Joe, and showed an affinity for soft substrate at C4-C5. There were many biases associated with the methods used, but sample sizes were large and the general trends were supported by the data.

Stomach content analysis and in situ observations indicated that $\underline{\mathbf{R}}$. californicus was a predator and scavenger, feeding on benthic, planktonic, and nektonic prey. This is similar to the feeding habits of its relatives (Table 4). If Labidiaster annulatus is the Antarctic ecological equivalent of Pycnopodia helianthoides (Dearborn, 1977), $\underline{\mathbf{R}}$. californicus fills the role of $\underline{P}$. helianthoides in the deep waters of the Monterey Submarine Canyon. What $\underline{\mathrm{R}}$. californicus and $\underline{\mathrm{L}}$. annulatus can do that $\underline{\mathrm{P}}$. helianthoides has not been observed to do is catch highly mobile swimming prey from the benthicwater column interface. The finding of another asteroid that can and does interact with water column organisms indicates that this phenomenon may be more common than 
previously thought. How much predation actually occurs and its effect on the nearbottom pelagic community remains to be determined.

Preliminary work indicates that the endoparasitic gastropod, Asterophila sp., found in $\underline{R}$. californicus from Monterey Bay, is a new species, and its presence here extends the geographical range of the genus around the coastal North Pacific. Because Asterophila sp. lacks strong, unique morphological characteristics, molecular work comparing samples from different hosts may help identify the species. Preliminary work by J. Geller (Hopkins Marine Station) has resulted in the extraction and amplification of Asterophila sp. genomic DNA. ROV observations indicated that the abundance of the parasite in the bay was spatially patchy, but more extensive sampling is needed for statistical analysis. The life cycle of Asterophila sp. and its method of dispersing its young remain enigmatic. 


\section{LITERATURE CITED}

Alton M. S. (1966) Bathymetric distribution of sea stars (Asteroidea) off the Northern Oregon Coast. Journal of the Fisheries Research Board of Canada, 23, 16731714.

Annett C. and R. Pierotti (1984) Foraging behavior and prey selection of the leather star Dermasterias imbricata. Marine Ecology Progress Series, 14, 197-206.

Arnaud P. M. (1970) Frequency and ecological significance of necrophagy among the benthic species of Antarctic coastal waters. In: Antarctic ecology, Vol. 1, M. W. Holdgate, editor, Academic Press, London, pp. 259-266.

Austin W. C. (1985) An annotated checklist of marine invertebrates in the cold temperate Northeast Pacific. Vol. 1. Khoyatan Marine Laboratory, Cowichan Bay, British Columbia, 218 pp.

Bernstein B. B. and J. P. Meador (1979) Temporal persistence of biological patch structure in an abyssal benthic community. Marine Biology, 51, 179-183.

Birkeland C. (1974) Interactions between a sea pen and seven of its predators. Ecological Monographs, 44, 211-232.

Bouchet P. and A. Waren (1979) Planktotrophic larval development in deep water gastropods. Sarsia, 64, 211-232.

Butler J. L., W. W. Wakefield, P. B. Adams, B. H. Robison and C. H. Baxter (1991) Application of line transect methods to surveying demersal communities with ROVs and Manned Submersibles. Proceedings, Qceans 1991 Conference, 2, 689-696.

Carey A. G. (1972) Food sources of sublittoral, bathyal and abyssal asteroids in the northeast Pacific Ocean. Ophelia, 10, 35-47.

Chia F. -S. and H. Amerongen (1975) On the prey-catching pedicellariae of a starfish, Stylasterias forreri (de Loriol). Canadian Journal of Zoology, 53, 748-755.

Cochran W. G. (1954) Some methods for strengthening the common $\mathrm{X}^{2}$ tests. Biometrics, 10, 417-451.

Crofton H. D. (1971) A quantitative approach to parasitism. Parasitology, 62, 179-193.

Dayton P. K. (1971) Competition, disturbance, and community organization: the provision and subsequent utilization of space in a rocky intertidal community. Ecological Monographs, 41, 351-387.

Dayton P. K. (1973) Two cases of resource partitioning in an intertidal community: making the right prediction for the wrong reason. American Naturalist, 107, 662-670. 
Dayton P. K. (1975) Experimental evaluation of ecological dominance in a rocky intertidal algal community. Ecological Monographs, 45, 137-159.

Dayton P. K., G. A. Robilliard, R. T. Paine and L. B. Dayton (1974) Biological accommodation in the benthic community at McMurdo Sound, Antarctica. Ecological Monographs, 44, 105-128.

Dearborn J. H. (1977) Food and feeding characteristics of Antarctic asteroids and ophiuroids. In, Adaptations within Antarctic Ecosystems, Proceeding of the Third SCAR Symposium on Antarctic Biology, G. A. Llano, editor, Gulf Publishing Co., Houston, pp. 293-326.

Dearborn J. H., K. W. Allen, J. C. Hureau and P. M. Arnaud (1972) Ecological and taxonomic studies of echinoderms, molluscs, and fishes from the Antarctic Peninsula. Antarctic Journal of the US, 7, 80-82.

Dearborn J. H. and F. J. Fell (1974) Ecology of echinoderms from the Antarctic Peninsula. Antarctic Journal of the US, 9, 304-306.

Dearborn, J. H., K. C. Edwards and D. B. Fratt (1981) Feeding biology of sea stars and brittle stars along the Antarctic Peninsula. Antarctic Joumal of the US, 1981
Review, 136-137.

Etchemendy S. and D. Davis (1991) Designing and ROV for oceanographic research. Sea Technology, February.

Fairweather P. G. and A. J. Underwood (1983) The apparent diet of predators and biases due to different handling times of their prey. Qecologia, 56, 169-179.

Feder H. M. and A. M. Christensen (1966) Aspects of Asteroid Biology. In, Physiology of Echinodermata, R. A. Boolootian, editor, Interscience Publishers, New York, pp. 87-127.

Fisher W. K. (1906) New starfishes from the Pacific Coast. Proceedings of the Washington Academy of Science, 8, 136-139.

Fisher W. K. (1923) A preliminary synopsis of the Asteriidae, a family of sea-stars. Annals of the Magazine of Natural History, 12, 247-259.

Fisher W. K (1928) Asteroidea of North Pacific and Adjacent Waters: Part 2. Forcipulata. Bulletin of the United States National Museum, 76, 245 pp.

Fisher W. K. (1940) Asteroidea. Discovery Report, 20, 69-306.

Fox L. R. and P. A. Morrow (1981) Specializaton: species property or local phenomenon. Science, 211, 887-893.

Greer D. L. (1961) Feeding behavior and morphology of the digestive system of the seastar Pycnopodia helianthoides. MSc. Thesis, University of Washington,
$88 \mathrm{pp}$. 
Grusov E.N. (1965a) Adaptation of gastropod molluscs to parasitism. Zool. ZH, 44, $1620-1630$.

Grusov E.N. (1965b) The endoparasitic mollusk Asterophila japonica Randall and Heath (Prosobranchia:Melanellidae) and its relation to the parasitic gastropods. Malacologia, 3, 111-181. (In Russian).

Herrlinger T. J. (1983) The diet and predator-prey relationships of the sea star Pycnopodia helianthoides (Brandt) from a central California kelp forest. M. S. Thesis, $57 \mathrm{pp}$.

Hoberg M.K., Feder H.M. and S.C. Jewett (1980) Some aspects of the biology of the parasitic gastropod, Asterophila japonica Randall and Heath (Prosobranchia: Melanellidae), from southeastern Chukchi Sea and northeastern Bering Sea, Alaska. Ophelia, 19, 73-77.

Hopkins T. S. and G. F. Crozier (1966) Observations on asteroid echinoderm fauna occurring in the shallow water of southern California (intertidal to 60 meters). Bulletin of the Southern California Academy of Science, 65, 129-145.

Jangoux M. (1982) Food and feeding mechanisms: Asteroidea. In: Echinoderm Nutrition, M. Jangoux and J. M. Lawrence, editors, A.A. Balkema, Rotterdam, pp. 117-159.

Kennedy C. R. (1976) Reproduction and Dispersal. In: Aspects of Animal Parasitology. C. R. Kennedy, editor, N. Holland Publishing Co., Amsterdam, pp. 143-160.

Kjerskog-Agersborg H. P. (1918) Bilateral tendencies and habits in the twenty-rayed Pycnopodia helianthoides (Stimpson). Biological Bulletin, 35, 232-254.

Kormondy E. J. (1984) Concepts of Ecology. New Jersey, Prentice-Hall, Inc., 298 pp.

Krebs C. J. (1972) Ecology. New York, Harper \& Row, Publishers, Inc., 694 pp.

Krebs C. J. (1989) Ecological methodology. Harper \& Rowe, Publishers, New York, $654 \mathrm{pp}$.

Lambert P. (1981) The sea stars of British Columbia. Handbook, British Columbia Provincial Museum, 39, $153 \mathrm{pp}$.

Larson R. L., G. I. Matsumoto, L. P. Madin, and L. M. Lewis (1992) Deep-sea benthopelagic medusae: recent observations using submersibles, a remote vehicle, and a ROV. Bulletin of Marine Science 51 (in press).

Mauzey K. P., C. Birkeland, and P. K. Dayton (1968) Feeding behavior of asteroids and escape responses of their prey in the Puget Sound region. Ecology, 49, 603-619.

McCauley J. E. (1972) A Preliminary checklist of selected groups of invertebrates from otter-trawl and dredge collections off Oregon. In: Columbia River Estruary and Adjacent Ocean Waters: Bioenvironmental Studies, A.T. Pruter and D.L. Alverson, editors, University of Washington Press, Seattle, pp. 409-421. 
Menge B. A. (1972a) Competition for food between two intertidal starfish species and its effect on body size and feeding. Ecology, 53,635-644.

Menge B. A. (1972b) Foraging strategy of a starfish in relation to actual prey availability and environmental predictability. Ecological Monographs, 42, 2550 .

Menge B. A. (1982) Effects of feeding on the environment: Asteroids. In: Echinoderm Nutrition, M. Jangoux and J. M. Lawrence, editors, A.A. Balkema, Rotterdam, pp. 521-551.

Morton J.E. (1979) Molluscs. 5th ed. London, Hutchinson University Library. 264 pp.

O'Brien F. X. (1976) Some adaptations of the seastar, Leptasterias littoralis (Stimpson) to life in the intertidal zone. Thalassia jugoslavica, 12, 237-243.

Paine R. T. (1966) Food web complexity and species diversity. American Naturalist, $100,65-75$.

Paine R. T. (1969a) The Pisaster-Tegula interaction: prey patches, predator food preference, and intertidal community structure. Ecology, 50, 950-961.

Paine R. T. (1969b) A note on trophic complexity and community stability. American Naturalist, 103, 91-93.

Paine R. T. (1974) Intertidal community structure: experimental studies on the relationship between a dominant competitor and its principal predator. Qecologia, 15, 93-120.

Paul A. J. and H. M. Feder (1975) The food of the sea star Pycnopodia helianthoides (Brandt) in Prince William Sound, Alaska. Ophelia, 14, 15-22.

Quayle D. B. (1969) Pacific oyster culture in British Columbia. Bulletin of the Fisheries Research Board of Canada, 169, 1-192.

Randall J. and H. Heath (1912) Asterophila, a new genus of parasitic gastropods. Biological Bulletin, 22, 98-107.

Rohde K. (1982) Ecology of marine parasites. University of Queensland Press, New York, $245 \mathrm{pp}$.

Robilliard G. A. (1971) Feeding behavior and prey capture in an asteroid, Stylasterias forreri. Svesis, 4, 191-195.

Rutherford J. C. (1973) Reproduction, growth and mortality of the holothurian Cucumaria pseudocurata. Marine Biology, 22, 167-176.

Sanders, H. L. (1960) Benthic studies in Buzzards Bay III. The structure of the softbottom community. Limnology and Oceanography, 5, 138-153. 
Shivji M., D. Parker, B. Hartwick, M. J. Smith and N. A. Sloan (1983) Feeding and distribution study of the sunflower sea star Pycnopodia helianthoides (Brandt, 1835). Pacific Science, 37, 133-140.

Sloan N. A. (1980) Aspects of the feeding biology of asteroids. Oceanography and Marine Biology Annual Review, 18, 57-124.

Sloan N. A. and S. M. C. Robinson (1983) Winter feeding by asteroids on a subtidal sandbed in British Columbia. Ophelia, 22, 125-140.

Smith C. R. (1985) Food for the deep sea: utilization, dispersal, and flux of nekton falls at the Santa Catalina Basin. Deep-Sea Research, 32, 417-442.

Taylor J.B. (1975) Planktonic veligers of Kaneohe Bay. Univ. Hawaii PhD Dissertation, $593 \mathrm{pp}$.

Uzmann J. R., R. A. Cooper, R. B. Theroux and R. L. Wigley (1977) Synoptic comparison of three sampling techniques for estimating abundance and distribution of selected megafauna:submersibles vs camera sled vs otter trawl. Marine Fisheries Review, 39, 11-19.

Verrill A. E. (1909) Remarkable development of starfishes on the northwest American coast; Hybridism; multiplicity of rays; teratology; problems in evolution; geographical distribution. American Naturalist, 43, 542-555.

Vevers H. G. (1951) The biology of Asterias rubens L. II. Parasitization of the gonads by the ciliate Qrchitophrya stellarum Cepede. Journal of the Marine Biological Association of the United Kingdom, 29, 619-624.

Waren A. (1983) A generic revision of the family Eulimidae (Gastropoda, Prosobranchia). Journal of Molluscan Studies, Supplement 13, 1-96.

Wobber D. R. (1973) Aboral extrusion of squid pens by the sea star Pycnopodia helianthoides. Veliger, 16, 203-206.

Zar J. H. (1974) Biostatistical Analysis. Prentice-Hall, Inc. Englewood Cliffs, New Jersey, $718 \mathrm{pp}$. 